THE MILWAUKEE COUNTY SCHOOL OF AGRICULTURE AND DOMESTIC ECONOMY

\title{
REPORT OF A SURVEY
}

MADE FOR THE

\section{MILWAUKEE TAXPAYERS' LEAGUE}

BY

\author{
WALTER MATSCHECK \\ Director of the Wisconsin Efficiency Bureau
}

MADISON, WISCONSIN

May, 1916 

THE MILWAUKEE COUNTY SCHOOL OF AGRICULTURE AND DOMESTIC ECONOMY

\title{
REPORT OF A SURVEY
}

MADE FOR THE

\section{MILWAUKEE TAXPAYERS' LEAGUE}

BY

\author{
WALTER MATSCHECK \\ Director of the Wisconsin Efficiency Eureau
}

MADISON, WISCONSIN

May, 1916 


$$
c_{472^{5}}^{531}
$$

$0 \quad 1 \quad i n+\infty$ 


\section{TABLE OF CONTENTS}

Chapter

Page

The SURVey ITSELF________ 6

I. SUMMARY OF Findings__._. 7

Lands, Buildings and Equipment _._._._. 7

School Records _............... 7

Students _._. 8

Enrollment and Attendance

Course of Study _......... 8

Teaching _... 8

Extension _... 9

The School Farm _........... 10

Finances _... 10

II. Discussion and Recommendations _.......... 11

The School' and the Community _........... 11

The School Farm _....................... 13

Domestic Science _..._._._._. 14

Students and Costs_._._. 14

Shall the School Be Abolished _..._._._._._. 14

III. The School in General _...

Organization _._. 16

History _.................. 17

IV. SCHOOL RECORDS _... 18

It is Recommended _..... 19

V. Land, Buildings and Equipment_..._..... 20

Land _._.

Buildings _................. 20

Equipment _...

Summary _............ 24 
Chapter

VI. STUdents _. 25

Homes _...

Ages _... 26

Previous Schooling _..._._._. 26

Farm Experience _......... 28

Fathers' Occupations _.................... 28

Length of Time Out of School_________-_ 28

Purpose in Coming to School _._._._._._._. 29

Credits and Hours of Work

Failures and Promotions _._._._._._._._._._. 29

Enrollment and Attendance _................ 30

VII. Graduates _... 31

VIII. Courses of STUdY _...

The Three and Four Year Courses_._._._._._. 33

Other Courses _... 36

A Suggested New Course_..._._. 36

IX. Teaching StafF _-

Training -

Salaries _._.

Hours of Instruction

X. TEACHING _.

Classroom Observations _._._._._._._._._. 39

Practices to Be Discouraged _._._._._._._. 44

Supervision of Instruction _._._. 45

XI. ExTENSION _- 47

Work Done _. 47

Cost

Summary _.

XII. THE School FARM _._. 51

The Farm Proper

Dairy _._. 51

Costs _._. 52

Can and Should the Farm Be Made a Paying Proposition 
Chapter Page

XIII. The School Finances 58

Financial Reports _..._.

History _...

Receipts_-Analysis _..._._._._._._. 62

Expenditures-Analysis _._._._._._._._. 63

Extension _._. 63

Per Capita Costs _._. 67

Dormitory Costs _._._._. 68

Class Costs _._. 68

Accounting _._. 70

Purchasing _._. 70

Budget Methods and Procedure _._.________ 70

Summary of Finances_._._._. 73 


\section{THE SURVEY ITSELF}

This study of the Milwaukee County School of Agriculture and Domestic Economy was made for the Taxpayers' League of Milwaukee. The affairs of the school have been under discussion most of the time since its founding in 1911, and it was felt that a thoro investigation would clear up many of the questions which were being asked.

The work of getting the information and writing the report occupied the time of the writer for three weeks. Miss Sara Rivet of the Central High School, Minneapolis, assisted in the work of class-room observation for three days.

Throughout the study the survey had the co-operation of all officially connected with the school. The County Board of Administration, the superintendent of the school, and his assistants were all very glad to help. They gave information and records freely, and were anxious to do all in their power. The Board of Administration at a conference with the surveyor unanimously voted that they welcomed the study and would gladly co-operate in giving such information as might be asked for. The superintendent of the school went over the facts used in detail with the surveyor and has approved them. This attitude on the part of the officials has served to expedite the work.

It is the purpose of this report to give all the facts as found from the study of the records, reports, documents and from conferences, consultations and observations. Each point made will be accompanied by facts verifiable by anyone who may wish to study them. Student, financial, and all other such records may be obtained at the school. Class and teaching reports are based on the survey's own observations. To officials and others who may wish to verify the observations, names and classes will be given that independent observations may be made if desired. 


\section{CHAPTER I}

\section{SUMMARY OF FINDINGS}

\section{Lands, buildings and equipment}

The official inventory taken in October, 1915, gives a total investment in the school of $\$ 345,963.84$. There are 206 acres of land, four main instruction buildings besides the dairy barn, and $\$ 40,000$ worth of equipment.

The buildings are more than sufficient to fill the needs of the school. Class rooms and laboratories are used but $32 \%$ of the time during the school day. The smallest room can, with but few exceptions, hold the largest classes. The school could very well have gotten along if two fewer buildings had been built.

Equipment is equally lavish. The statement that it rivals that of many an agricultural college is borne out by observation and study of the equipment inventory. Tho teaching children of secondary school age and preparation, the equipment would be equally well adapted for college students, and is far beyond that included on the average farm.

The expenditures for equipment have been made with little thought of amount of use to which purchases would be put, actual need for them, or the pupils for whom they were to be used. There is one cow for every five boys enrolled. There is one class room or laboratory room in the four main buildings for every seven pupils enrolled. The total school investment is nearly $\$ 3,000$ per pupil in average daily attendance.

\section{School records}

School records are not adequate to give definite information on many school activities. Extension work can scarcely be even estimated either in time spent or in cost. Enrollment statistics, course statistics, room schedules, are only partly available. Cost figures of all kinds are in very bad form. The profit and loss, for example, on the farm could only be determined after much computation. The superintend- 
ent makes no report of any kind in written form to the board of administration. There is nowhere any place where a citizen can quickly get a statement of the financial and other affairs of the school.

\section{Students}

There was in 1914-15 a total enrollment of 191-124 boys and 67 girls with an average daily attendance of 118 . 59\% of the boys and $52 \%$ of the girls in 1915-16 came from the city of Milwaukee. A large additional percentage came from other cities or towns. $74 \%$ of the boys and $70 \%$ of the girls are of ordinary high school age. 18 boys and 9 girls are over 20 years of age. A majority of the pupils have only an eighth grade education or less on entrance to the school. A large number have part of a high school course, but only a few have completed or gone beyond this.

41 , or $34 \%$, of the boys had either no farm experience or three months or less. 36 , or $30 \%$, had one year or more.

The children come from the families of the working man and of the middle class man. This is shown by the list of fathers' occupations. There are probably no pupils who come from wealthy families.

\section{Enrollment and attendance}

The enrollment has been decreasing steadily since the first year of the school-1912-13. This year's figures are not yet available and it cannot be definitely stated whether or not there will be a further decrease.

\section{Courses of study}

The courses of study consist of a three year and a four year course in agriculture, a three year and four year course in domestic economy, and special courses-cooking and sewing classes, special eighth grade classes, and classes from the Home for Dependent Children. The four year course admits to the University. The three year course contains all that is in the four year course with the exception of the academic work. The addition of academic work allows the school to give the equivalent of a high school course in connection with the agricultural course.

\section{Teaching}

Teaching was found to contain examples of good work and of poor work. No teacher or class was judged as a whole. The method used was to report what occurred in the classes visited and to point out 
those methods or practices which need to be encouraged or discouraged. Practices seen which violate pedagogical principles are

Book open before instructor

Constant reference to text by instructor

Lack of discipline

Calling on pupil before asking question

Preventing discussion on part of pupils by dragging them back to

text or answering questions which other pupils could answer

Discouraging questioning on the part of pupils

Instructor doing most of the work

Lack of explanation by instructor of work he is doing

Lack of correlation between laboratory and class-between the work of different classes

Not telling pupils what they are doing and why

Not permitting students to go thru the whole process from beginning to end

Distracting the attention of pupils by interruptions

Lack of respect for teacher on part of pupils

Cheating by pupils

Indistinct speech on part of teacher and pupils

Overmuch memory work and insufficient reasoning by pupils

Lecturing to small classes

Supervision of instruction is either inadequate or conducted without the spirit of helpfulness, so that it accomplishes little in the way of eliminating these defects. If supervision were properly conducted practices observed in the classrooms could not continue.

\section{Extension}

Extension work is unorganized and undeveloped. The largest feature is the special classes conducted at the school. Work which is done outside consists of lectures and direct aid to farmers. The latter would take the time of one man for two days a week. Yet it is valued in a school statement on the basis of a man's full time.

The special classes consist largely of courses in domestic science which women from the city come out to take one afternoon a week during the spring and fall terms. These courses with a series of lectures in the Milwaukee Public Library, a two weeks' summer course for rural teachers with an attendance of thirty, and some lectures at social centers constitute the greater part of what is called extension. It is estimated that these activities cost one-sixth of the total operating expense, or about $\$ 8,000$. No definite cost or time records are kept. 


\section{The school farm}

The farm runs at a profit if investment is left out of consideration. But how much of a profit, and just where it is, can not be determined from the school records without a large amount of work. It has a very desirable location as a farm for the intensive cultivation which preva!!s in the county. Of all its facilities - expert advice and assistance, the opportunity to teach the pupils by having them do actual work, - the school is not making the best possible use. It returns $\$ 10,000$ gross receipts annually to the county of which from $\$ 3,000$ to $\$ 4,000$ comes from the dormitory. This leaves but $\$ 6,000$ to $\$ 7,000$ return from the farm, dairy and poultry. The net profit, not counting interest on investment is less than $\$ 1,500$. The problem to be worked out, which there seems to have been little effort to work out, is how to so utilize the facilities as to get a maximum of teaching from actual farm work, and turn in at the same time a substantial profit.

\section{Finances}

The cost of the school is excessive. With an enrollment of 191 and an average daily attendance of 118 , for the year 1914-15, the expenditures were $\$ 52,590.02$. On the most equitable basis of figuring cost this is $\$ 334.52$ per pupil, or $\$ 494.71$ if the investment is considered. Net cost (allowing for farm receipts) to the county and state is $\$ 281.35$ without investment, or $\$ 441.54$ with. On the basis of total cost (including investment) there is no tendency toward reduction. In $1912-13$ it was $\$ 439.91$; in $1913-14, \$ 463.96$; and in $1914-15$, $\$ 441.54$, or more than the first year.

The dormitory is not run on a business basis. It does not have a deficit, but this is because investment is not considered, so it makes little difference whether it is kept full or not. With accommodations for 40,37 was the highest number in residence at any one time this year, and the present number is 20 .

Cost by classes varies from $\$ 2.67$ to $\$ 26.32$ per hundred student hours. This is the salary cost alone. No records of this kind are kept or worked out by the school.

Budget methods are very rudimentary. The budget as submitted contains nothing beyond requests. These are approved, with a few changes, without supporting evidence of any kind. Among information needed and not given is

Past expenditures-detail and summary

Increases or decreases-detail and summary

Reasons for changes

Per capita costs

Class costs

Farms costs - expenses and sales

Work program for year 


\section{CHAPTER II}

\section{DISCUSSIONS AND RECOMMENDATIONS}

There are two alternatives open to the people of Milwaukee County. One is to abolish the school, as has been moved in the Board of Administration. The other is to improve work and lower cost so that the people receive a more adequate return on the investment made. In the following discussion, which embodies the conclusions and recommendations of this study, these two alternatives should be kept in mind. If the arguments presented, together with the detailed facts which follow, prove to the citizens of the county that the school fills no useful place in the community, or that it can not do so at a cost which is reasonable, then the course to follow is to abolish the school. If, on the other hand, it proves that the school fills a useful place and work can be so improved and cost so reduced as to justify its continuance, then the school should be continued. The one course that should not be followed is to permit the school to run on the present basis.

\section{The school and the community}

Milwaukee County is not to a very large extent an agricultural county on account of the fact that it includes Milwaukee-Wisconsin's largest city. The farming that is done is chiefly dairying and market gardening. The place of a school of agriculture in such a community would be to teach this kind.of agriculture and to improve this kind of farming. It may be taken for granted that this was the purpose in view when the school was established. For training boys in dairy work and for truck garden work there is obviously an opportunity in this county. Is the school meeting it? Dairy work is stressed more than truck gardening. Neither are made the prime purpose in a boy's course. The emphasis is placed rather on the general educational value of agricultural training, its value as a preparation for life. It is this which led to the adoption of the four year course. It was felt that some incentive was needed to induce boys to stay in school for three years or more.

Here lies the difference of opinion-is it the purpose of the school 
to train boys to be farmers, or is it to train them to go into other work? Is its purpose specific or general? If specific, then the work should be made more specific. If general, is there any reason for the equipment provided for specific work, and is a cost which is excessively high for agricultural training at all justifiable for general training? It seems safe to assume that the purpose in establishing the school was to train boys to be farmers and to better farm conditions. It is also safe to assume that the boys in mind as beneficiaries were chiefly farm boys. It has been asserted that the purpose was to give the city boy a chance to learn agriculture if he so wished, but it is hard to believe that this is to any great degree a "back to the farm" movement.

If the school was established to reach the farm boy it is failing in its purpose. 71 of 121 boys come from Milwaukee City, 25 more come from other large Milwaukee County industrial centers. Of the remaining 25, part come from cities and towns outside of the county and a part come from small towns or farms within the county.

15 of 24 boy graduates are now doing some kind of agricultural work. What becomes of the large number who never graduate is not known, except that it is stated that most leave school to go to work, and of these many go to farms.

The school if it is to do its best work must get a larger proportion of boys who have done and who expect to do farm work. It may be that this is not possible. Every summer faculty members are sent out in the field seeking students, and so far they have not succeeded in preventing a decreased enrollment. The city supplies the majority of the pupils. So far as the survey could learn the early criticism that the boys who came from the cliy were the "bad boys" and "outcasts" of the town does not hold true at present to a very great extent, tho it is probably true that there are some of these boys in attendance.

Not only must the school get a larger enrollment of farm boys but it must get a larger total enrollment. The buildings and equipment are extensive enough for a much larger number of pupils. So long as a plant large enough to accommodate 300 to 400 runs with 118 the cost must be excessive. If enrollment were increasing the outlook might be more hopeful, but a steady decline since the first year does not indicate that the school will be used to capacity for some time to come.

The other phase of school activity in relation to the community is the extension work. Is this filling a useful place? There is no doubt that much of the work performed is of value but the total amount done is not large. The greater part consists of extra classes at school in which effort is made to get men, women, and children out for a few days or a few weeks of special instruction. Women come from Milwaukee for cooking, sewing, and millinery; rural teachers come for an eight Satur- 
day course, farmers come for a three day course. The members of the faculty give lectures in the city and in social centers. They also do direct work with the farmers which as has been stated would take the time of one man two days a week.

This is all very good but a large part of it is not really extension at all. The real extension work, out around the county, does not seem to require much time. This may be due to lack of aggressiveness on the part of the school. It is more likely that it is due to the fact that Miiwaukee County is largely industrial. This is a fact that must be faced. Agricultural extension work must necessarily be limited. This does not mean that the school is reaching the limit. There is no doubt much more opportunity, but it will require effort to develop it. Farmers' institutes away from the school, a short course in special agricultural suljects, correspondence work, club and social center work, farm and home demonstrations, are all fields for development. Extension work is at present carried into the city. A course of popular lectures on farm topics is given in the public library. It may be asked whether it would not be more productive of good to talk to seventy-five farmers on an agricultural topic than to seventy-five city people.

\section{The school farm}

Even though Milwaukee County is not a farming county, it does have dairying, fruit and berry growing, and truck gardening. It is along these lines that the school must develop. So far as it emphasizes any part of its work it already emphasizes dairying. The dairy work, orchard work, and garden work should all be made to pay a part of the expense of the school. This should be done by a larger use of student work. The teacher who cannot inspire the pupil with a sufficient liking for the work to cause him to feel that it is part of his duty and education to make the school farm pay has no place in a school of this kind. No more has the pupil who does not take sufficient interest to want to learn by actual experience how to make a farm pay, a place in the school. Here lies the opportunity of the school if it has any. The school cannot be conducted along the lines of most agricultural schools. It has a special problem in location, in pupils, and in work to be done. It will have to meet this problem in a new way. If the leadership is strong enough and the vision big enough it can work out a successful institution which will be an asset to the community. But it will have to work out each problem that comes up. It will have no precedents to follow. And the first step will be to break away from many old ideas. A course coextensive with the agricultural year should be a suggestion worth trying out. 


\section{Domestic science}

The discussion up to this point has dealt mainly with the agricultural part of the school. The reason is that the agricultural part is the most important part in enrollment, in expenditures, and in every other way. Domestic science teaching in this school does not have a special problem to the extent that agriculture has. Its main work is to learn how to connect the work in domestic science with the work in agriculture. Girls take very little work in agriculture in the school, tho there are many phases that are of especial interest in connection with domestic science.

Domestic science teaching can be directly connected with the idea of an agricultural school suited to Milwaukee County needs. Greenhouse instruction, horticulture, and landscape gardening can be given. Garcening, fruit growing, and dairying all lead to the home. The domestic science department can work out methods of utilizing the products of the farm in a way which will be of benefit to the pupils and to the school. Wisconsin is one of the greatest canning states in the country. Here is an industrial-agricultural opportunity for study.

\section{Students and cost}

Students come to the school to be taught. The instruction they receive is expected to train them to become agriculturalists, if not farmers. They now receive instruction which for its cost should be of the best. Specific defects have been pointed out elsewhere in this report. Here we shall call attention to the fact that it is possible to teach a practical subject in an unpractical way. This can be overcome by more outside work; by giving each pupil something definite to do; by giving him some responsibility; by making him part of the whole scheme of the school and showing him where he fits in this scheme.

That the school is not increasing its attendance indicates that the school is failing to impress the people with the idea that it can make it worth while for them to send their children to it. That it is not decreasing its too high cost indicates that it is not giving attention to the fact that it is a public institution and must answer to the public for its conduct. A per capita cost of $\$ 442$ is a cost which demands a reason or a lowering. Even the highest class of teaching would not account for it. This item alone will justify serious questioning by the board of administration, the board of supervisors, the state, and the taxpayers. If this cost cannot be brought down to a reasonable figure the school cannot justify its existence.

\section{Shall the school be abolished?}

This question the report will not attempt to answer. It is a question which the county authorities and the public must decide. It is the 
function of this report to give the situation and the facts on which to base a decision. The opportunities for improvement and lines to be followed, the places where improvements are essential, suggestions and recommendations, are given. If it is felt that on the showing made the school should continue, it should be allowed another chance. If it is felt, on the other hand, that the school fills no need, that it cannot be improved to the point where it will be justified on the basis of work and cost it will be abolished. The difficulties to be overcome may suggest that this will be the easiest way out. But there is a possibility of a very successful institution if real effort is made and real thought given to the subject.

This question of abolishing the school has been discussed at such length because of the motion made in the board of administration on April 26th to close the school and use the buildings for other purposes. If it is decided to do this there are many uses to which the county could put the buildings. A plan has already been suggested in the board of administration.

It should be remembered that abolition is not the only remedy. If the school were run on a smaller building and equipment scale there would be reductions in the upkeep expense. One or two buildings might be closed if the county could find other suitable use for them. This reduction could be accompanied by reductions along other lines. Such a course would give the school an opportunity to grow. If it is possible for it to increase its attendance in the future so that the buildings would all be necessary they could again be made available. 


\section{CHAPTER III}

\section{THE SCHOOL IN GENERAL}

\section{Organization}

The Milwaukee County School is one of the schools established under the state law giving state aid to any school maintained by one or two counties for the purpose of giving instruction in agriculture and domestic science. The 1915 legislature limited the giving of state aid to seven such schools, which is the number now in existence. The state agrees to pay the salaries of teachers up to $\$ 6,000$ a year for any school where the average daily attendance is less than $112, \$ 7,000$ where such average daily attendance is 112 and less than 137 , and $\$ 8,000$ where such average daily attendance is 137 or over. Under this provision the Milwaukee County school received $\$ 7,000$ from the state in $1914-15$.

Originally each of the schools was governed by a "County School Board" consisting of two members appointed by the county board of supervisors, and the county superintendent of schools. This systern still obtains in all of the schools except the Milwaukee County school. In 1915 a state law was passed providing for a "County Board of Administration" in Milwaukee County which should have charge of eight different county institutions, one of which was the School of Agriculture and Domestic Economy. This board consists of five members-thr 23 appointed by the county boar 1 of supervisors, and two by the governor of the state. They hold office for five years, and receive annual salaries of $\$ 3,000.00$. Provision is made for the expiration of the tern of office of one member each year. This law was challenged, and a decision in which it was upheld was rendered by the Supreme Court ot the state on April 4, 1916.

The state superintendent of public instruction and the dean of the state college of agriculture approved the course of study of the school at the time of organization, as required by law. The school makes an annual report of enrollment, attendance, and finances to the state superintendent. On the basis of this repoit the superintendent authorizes the payment of state aid. 


\section{History}

The early days of the school were unhappy. Due to lack of foresight or insufficient investigation of the field for such a school, it started out on an inflated basis. The idea of a county institution to instruct in the practical subjects of agriculture and domestic science took deep root. It was to be open to pupils who could not by reason of lack of training, age, money, or other reason, go elsewhere. As is often true in such cases no thoro investigation was made. Instead a very complete plant was built and then by "booming" advertising methods a large enrollment was built up the first year-1912-13. In this year 243 pupils entered. That this was not what should have been normally expected is shown by the fact that in the next year, 1913-14, the enrollment dropped to 206, and in 1914-15 it went still lower to 191 . Average daily attendance in the same years was 146, 135, and 118 . The 1915-16 figure will not be available until the end of the present school year.

The present superintendent entered on his duties with a heritage of over-expansion and a school debt of $\$ 10,000.00$, handed down to him by a predecessor.

This brief touch of history is given only for the purpose of furnishing a background for a clearer understanding of present conditions. 


\section{CHAPTER IV}

\section{SCHOOL RECORDS}

In making this study one of the main difficulties encountered was the lack of adequate records in the office of the school. In this respect it is like many small schools where for the ordinary purposes of the superintendent and his assistants it is possible to keep a working knowledge of each pupil, of buildings, of classes, etc., in mind without the use of cetailed written records. But for the purposes of the board of administration, of the board of supervisors, and of interested citizens, written records which tell of actual conditions are a necessity. They are also necessary for the superintendent if he desires to make a written report.

Data which the survey could not get at all, or could not easily get from records at the school, follow

Present enrollment of students by courses

Present enrollment of students by subjects

Place of meeting (room and building) of classes

(Except by working thru class schedule) courses, number of hours of class, time of meeting of classes, courses of each instructor

Cost and expenditure of farm, with profit or loss

Cost and expenditure of dairy, with profit or loss

Cost and expenditure of cafeteria, with profit or loss

Capacity of rooms (class, laboratories, etc.)

Amount of actual work required of pupils on farm, in dairy, etc.

Amount, character, distribution, and cost of extension work

Definition of the division of powers or functions as between the superintendent, the board of administration, and the board of supervisors

Record of supervision of instruction

Whenever in this report data on these subjects is used they were gotten by slow, roundabout methods, were made from actual observation without records, or are estimates of the school officers or the surveyor.

A system of records which will make it easier for the board of administration or others to find any facts they desire to know about the 
school is absolutely necessary for the efficient administration of the school.

\section{It is recommended}

That a card system of student records be installed. At present there are enrollment cards which are seldom completely filled out. It should be insisted on that these give all the information called for. The record of pupils, subjects, marks, credits, date of entrance and graduation or leaving school are now typewritten and inserted in a book. A system of cumulative records sheets on which marks would be entered at the end of each term would make each record available complete at any date and would save labor.

That reports on enrollment, attendance, classrooms, and hours be required of instructors or otherwise obtained and filed in easily accessible form. Daily attendance records are kept at present in an attendance book. These are necessary to determine average daily attendance.

That a record be kept of all extension work showing time spent, cost, kind of work, number of calls, attendance at meetings.

That the present records kept by the farm foreman on cost of farm ner field, and all records of sales, transfers and costs, be put in such form as to show definitely cost of each department, and especially of farm, dairy, dormitory, and cafeteria.

That all other records which are now kept only in the mind of the official or officials concerned be put in such form as to make them readily usable by others.

Another important document which is wholly lacking is an annual or biennial report by the superintendent. No written report of any kind is now made to the board of administration. While the school was governed by a separate board, the bookkeeping was done in the school office and the superintendent made a quarterly financial statement to the board. Since most of the bookkeeping has been transferred to the central office no report of any kind is made, except such as is sent in letters to the board in answer to inquiries. It is recommended that the superintendent make an annual report to the board of administration giving financial records, enrollment and attendance figures in detail, teaching force, course of study, improvements and changes made, new work or lines of work added or planned, graduates, extension work, special work, and all other important information having to do with the work of the school. This report should be printed and made available to the public. Such a report would require for its preparation most of the records recommended. 


\section{CHAPTER V}

\section{LAND, BUILDINGS AND EQUIPMENT}

\section{Land}

The school owns 206 acres of land including the campus proper. This land was originally purchased for $\$ 350$ an acre, making a total investment of $\$ 72,100$. The farm and campus are located about a mile from the city of Wauwatosa and 5 miles from the business district if Milwaukee. (For use of farm, see Chapter XII.)

\section{Buildings}

There are four main buildings used for class purposes. In addition there are the dormitory, the power house, greenhouses, dairy barn, poultry sheds, and other small buildings. The inventory values these as follows

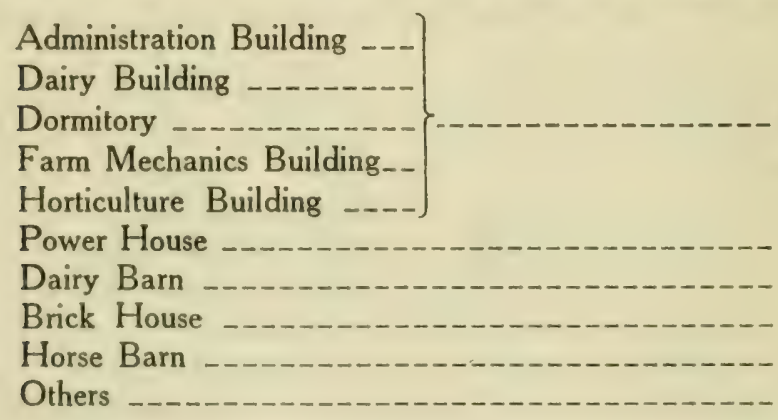

These four class buildings and the greenhouses contain 23 classrooms and laboratories. The classrooms seat from 20 to 56 students each. In addition to the classrooms and laboratories there are: in the Administration Building-locker room, rest rooms, library, practice home (with bed and bath room, drawing room, dining room, kitchen and large pantry), gymnasium (entire third floor); in the Dairy Building- 
music or assembly room with chairs for 160 , and dairy room with modern machinery occupying the entire basement; in the Farm Mechanics Building-machine shed.

For the second term of the present year seven classes met the first period Monday, six the second, six the third, five the fourth, nine the fifth, six the sixth, nine the seventh, and nine the eighth, or a total of 57 classes daily. To carry this load, for the whole day there were twentythree classrooms and laboratories available eight periods each, or 184 periods. This means a percentage of room use for the day of 31 per cent. On Tuesday the percentage was 32 , on Wednesday 33 , on Thursday 32, (one period was given over to assembly and is not counted), on Friday 34. There are no classes on Saturday. For the whole week the percentage was 32 (total number of periods use possible divided by total use actual).

For the first period throughout the week the percentage of use was 33. for the second period 32, for the third period 34, for the fourth period 29 , for the fifth period 34 , for the sixth period 30 , for the seventh period 35 , and for the eighth period 31 .

None of these figures takes into account the work which was done out of doors, or in other than classrooms or laboratories. It does, however, include two rooms in the greenhouse which cannot be used all the time because an insufficient number of classes use greenhouses. It is also true that in some laboratories there are not sufficient drawer arrangements for full use. This could be overcome in case of necessity by a system of lockers.

Due to the lack of complete records showing in what rooms classes meet and numbers of pupils in classes it was not possible to show for each room and building percentage of time used, and proportion between size of classes and seating capacity of rooms. For a number of classrooms and classes, however, it is possible to show this proportion, and the random illustrations will be sufficient to show the general relation

One classroom with seats for 32 held classes of 13,21, 6, 4

One with 23 seats held a class of 7

Two rooms with seats for 20 and 32 held classes of $5,10,9,14$, $8,2,12,22$

The largest class had an enrollment of 30 . The smallest classroom had 20 seats. The largest classroom had 56 seats. There were only twelve classes (meeting 43 times a week out of a total of 289 class meetings) in the second term which could not be seated in the smallest classroom.

The conclusion seems inevitable that the school has more room than it can use. After providing for extra rooms for all purposes including rest rooms, store, practice home, locker rooms, music rooms, there remain 
so many class rooms that they are used only $32 \%$ of the time during the school day. Some rooms are used more and some are used practically not at all. Not only this but rooms used are never filled to capacity or nearly capacity.

It is not here assumed that all room should be used to $100 \%$ capacity cither in time or pupils. $100 \%$ might be the ideal, $75 \%$ might be the possibility in the average school, but $33 \%$ shows poor foresight, inadequate previous investigation, and extravagance.

This is the condition which exists. Merely from the point of view of use it is hard to see what can be done about it unless one of the buildings can be used by the county for other purposes. The main interest in this showing will appear, however, when considered in relation to other points to follow.

\section{Equipment}

When considered in relation to the ages, training, and purposes of pupils enrolled the equipment of the school is very extensive. On a snaller scale the equipment of the agriculture department rivals that of rnany an agricultural school of college grade. In domestic science it is equally lavish, including a completely furnished practice home of four rooms, cooking laboratory with all supplies, and a sewing laboratory with eight sewing machines.

To illustrate agricultural equipment the dairy inventory will be a very good example. This is taken from the complete inventory of school as made October 8, 1915. To save space only the larger and more costly articles are given here.

No. Article.

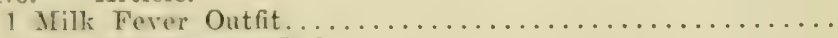

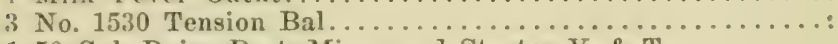

150 Gal. Dairy Past. Mixer and Starter V. \& T..........

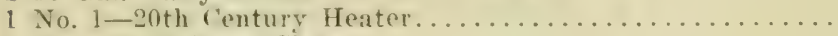

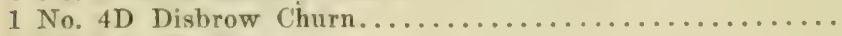

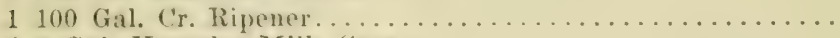

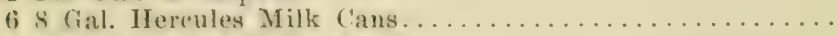

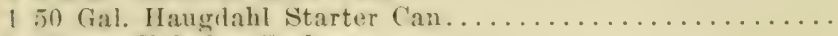

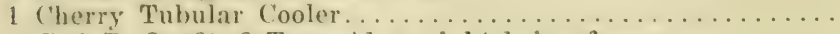

1 C. \& B. Outfit, 2 Type Al. upright brine freezer.........

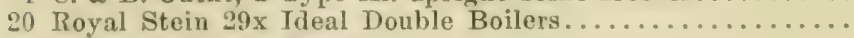

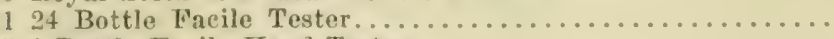

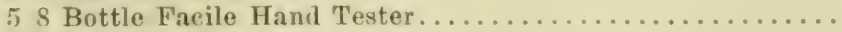

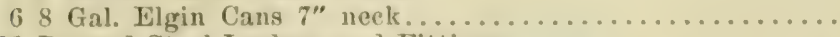

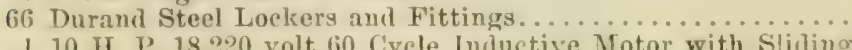

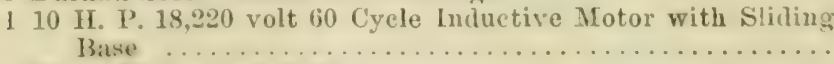

45.00

121.50

65.25

65.00

150.00

12.60

65.00

61.75

265.00

8.00

20.00

40.00

13.50

251.85

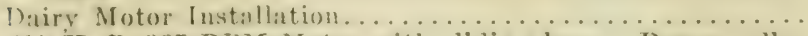

$171 / 2$ H. P. 865 RPM Motor with sliding base. Paper pulley

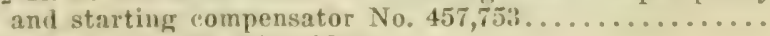

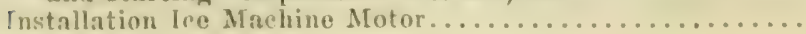


12 H. P. 560 RPM Motor with sliding base and pulley No.

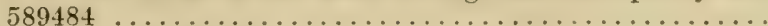

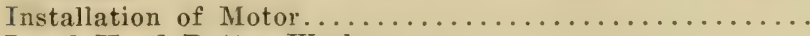

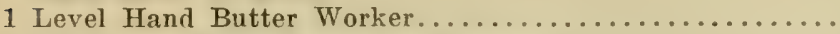

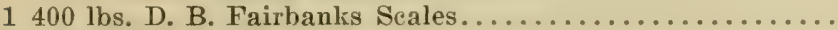

68 Gal. Milk Cans.............................. 13.50

1 No. 1 Up-to-date Butter Printer................... 3.20

2 Doz. 30 lb. returnable Butter Boxes................ 5.00

1 No. 2 Conical Milk Cooler......................... 5.60

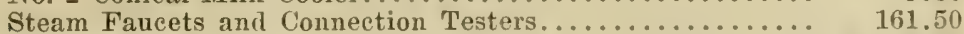

1 Refrigerating Plant ...................... 1,542.25

To furnishing and connecting cork insulation........ 487.00

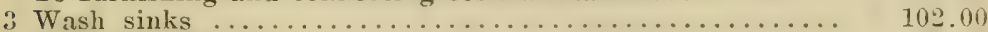

3 Gal. Lab. Sinks............................. 49.50

Sterilizer ........................... 237.41

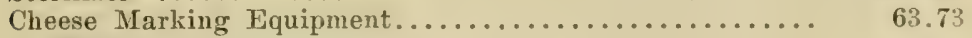
Stock.

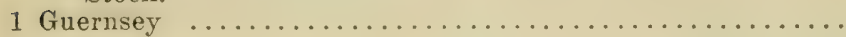

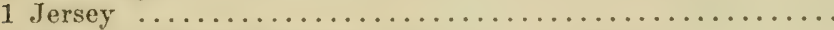

500.00

200.00

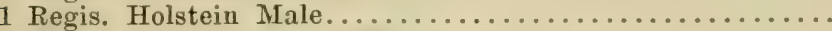

100.00

125.00

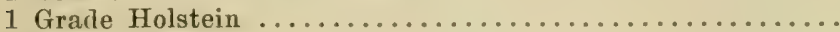

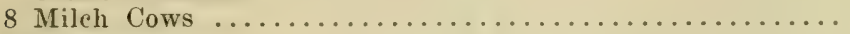

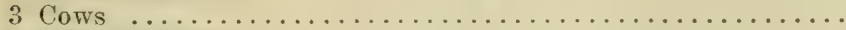

$1,000.00$

380.00

275.00

180.00

300.00

45.00

50.00

35.00

300.00

100.00

75.00

150.00

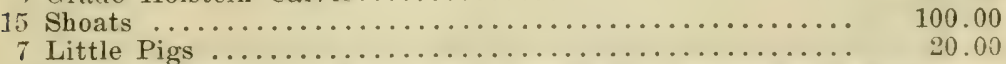

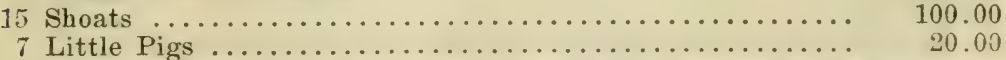

The total cost value of all dairy equipment including live stock, ail? items not here listed is $\$ 10,274.47$. with an estimated depreciation of $\$ 801.96$.

The library of the school is not so complete as is equipment along other lines. It contains 651 volumes of reference books, 160 volumes of general reference books (academic works, dictionaries, etc.) 263 volumes of fiction, and a large number of text books which are loaned to pupils. About 40 journals are subscribed to regularly and these are agricultural and trade papers in large part. There is also a collection of bulletins.

The total estimated present value according to the inventory of supplies and equipment for all departments is $\$ 39,986.84$.

The extensive equipment of the school means that there has been plenty of money available for almost anything that was wanted. This encouraged and brought about extravagance. The work along the same lines in other schools in the state teaching agriculture with a fractional 
part of the equipment would tend to show that it was in large part unnecessary.

A number of questions arise from these facts:

1. In order to teach agriculture to boys of from thirteen years of age up, a large proportion of whom are city boys, is it necessary to have the equipment of the most specialized farm in each department?

2. Will the training thus given teach such boys the methods of practical farming, or will it tend to make them helpless on a farm without much high-priced, ready-made equipment at hand?

3. Will such completeness not prevent the inculcation of habits of self-reliance, invention, and ingenuity?

4. Is a herd of 38 necessary for a school enrolling 121 boys in the department of agriculture, only a small proportion of whom take dairying at any one time?

As in the case of buildings this reflects on past methods. With the extensive equipment on hand nothing additional need be purchased for some time to come even with a large increase in the number of students. The need of careful investigation of all requests for large items of equipment is apparent, and in the future such requests should be allowed only after a complete demonstration of actual necessity. The new board of administration is employed for full time. Devoting their full time it should be possible, and it should be a rigidly enforced duty, for them to see that every financial request they make of the county board of supervisors represents a thoroughly investigated and demonstrated need.

\section{Summary}

The total financial investment represented by the school is

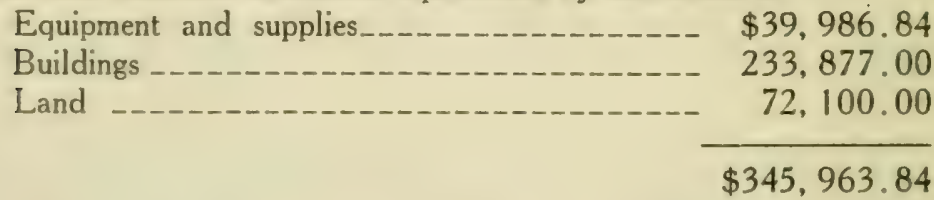

On the basis of the 1914-15 enrollment of 191 pupils this is $\$ 1,811.33$ per pupil. Using the average daily attendance which represents more nearly the actual attendance at the school, it is $\$ 2,931.05$. (For more detailed cost data, see Chap. XIII.) 


\section{CHAPTER VI}

\section{STUDENTS}

The following analysis of the pupils of the school was made from the 1915-16 enrollment cards of regular pupils. Wherever for any student the information was not given it is indicated here under the head "not given".

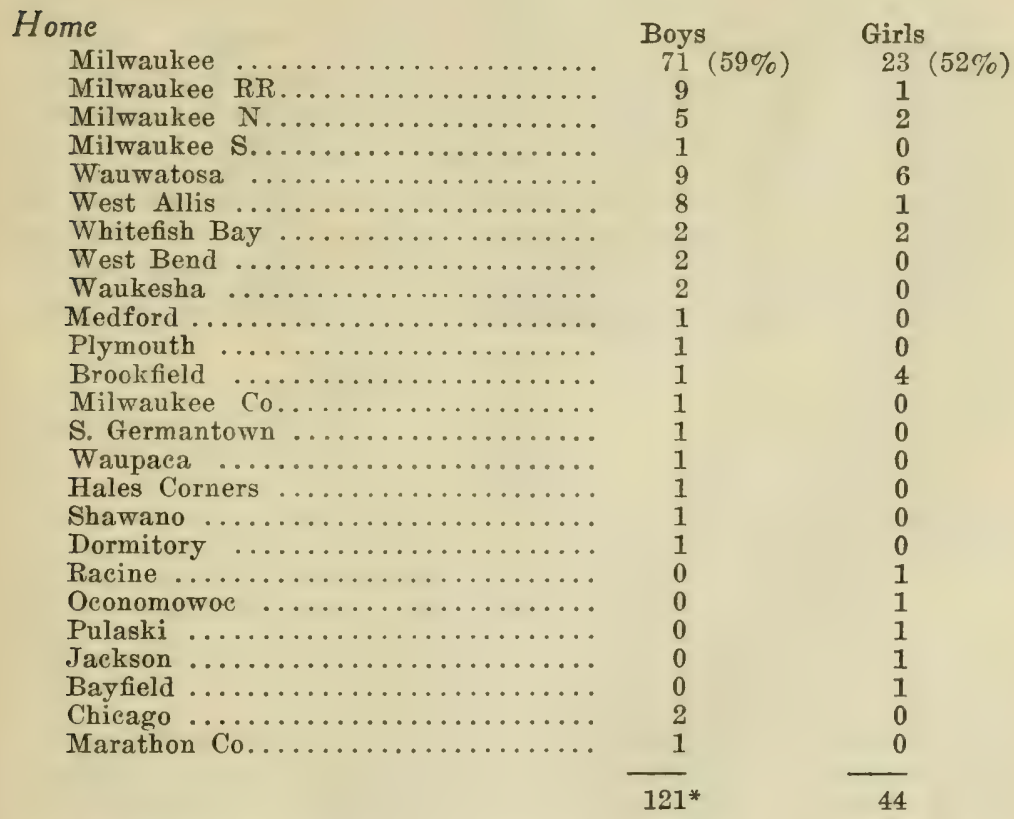

This shows that $71(59 \%)$ of a total of 121 boys, and $23(52 \%)$ of 44 girls come from the city of Milwaukee. Two boys come from outside of Wisconsin and 11 boys and 11 girls come from other counties than Milwaukee.

* Data for one pupil lacking. 
Ages

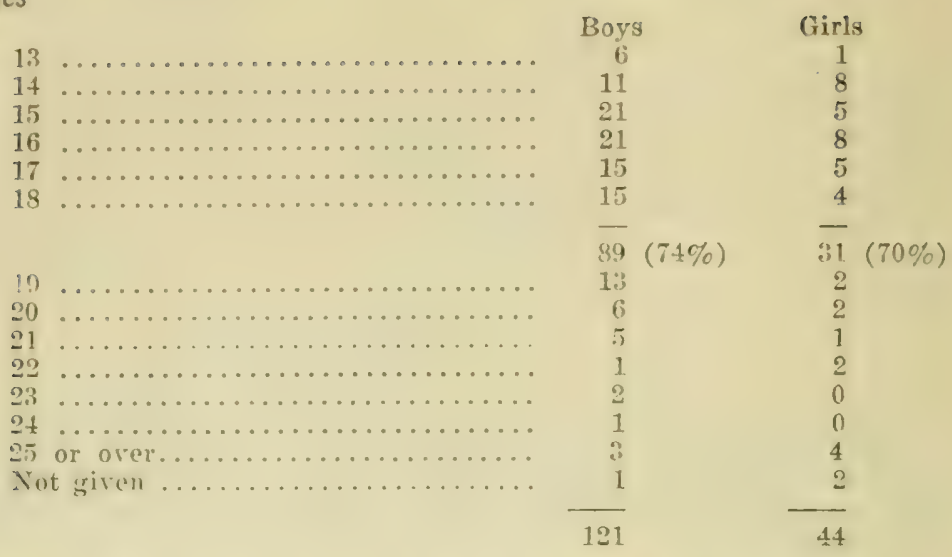

89 , or $74 \%$, of 121 boys and 31 , or $70 \%$, of 44 girls were of ordinary high school age, while 32 boys and 13 girls were older. The point to be remembered is that the school has chiefly pupils of high school age and grade. This is even more evident from the next table which shows that only three boys and seven girls had finished a high school course. That is, even the pupils older than ordinary high school age have generally less than a high school previous training. This, of course, does not mean that many of the older pupils have not a larger and more mature grasp and mental development than the average high school pupil.

\section{Previous schooling}

\begin{tabular}{|c|c|c|}
\hline & Boys & Girls \\
\hline 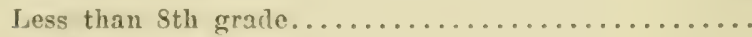 & 7 & 3 \\
\hline$\ldots \ldots \ldots \ldots \ldots \ldots \ldots \ldots \ldots \ldots \ldots$ & 47 & 23 \\
\hline 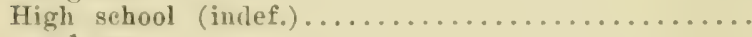 & 4 & 0 \\
\hline 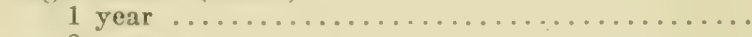 & 18 & 2 \\
\hline 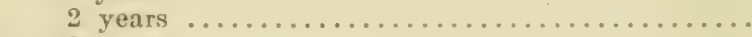 & 7 & \\
\hline 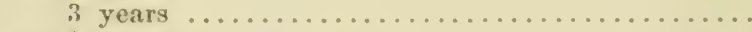 & 4 & \\
\hline 4 years $\ldots \ldots \ldots \ldots \ldots \ldots \ldots \ldots \ldots \ldots$ & 2 & 2 \\
\hline Aearlemy . . . . . . . & 2 & \\
\hline Marquette Aratemy 8 years. $\ldots \ldots \ldots \ldots \ldots \ldots \ldots \ldots$ & 1 & \\
\hline Marquette Acalemy and Business College.......... & ] & \\
\hline 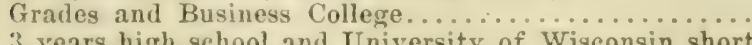 & 3 & \\
\hline 3 years high sehool and University of Wisconsin short & & \\
\hline $\begin{array}{r}\text { course } \\
\text { rounty agrioulture } \\
\ldots \ldots\end{array}$ & 1 & \\
\hline $\begin{array}{l}\text { ounty } \\
\text { Not given } . \ldots \ldots \ldots \ldots\end{array}$ & 5 & \\
\hline 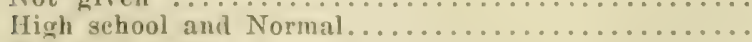 & & \\
\hline 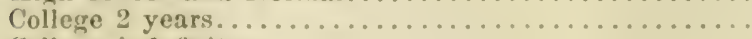 & & 2 \\
\hline College indefinite $\ldots \ldots \ldots \ldots \ldots \ldots \ldots \ldots \ldots$ & & 1 \\
\hline 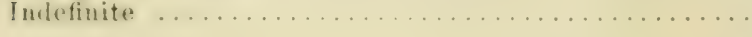 & & \\
\hline & 121 & 44 \\
\hline
\end{tabular}


The state law providing aid for county schools states that the schools shall be open to any pupil who has completed the eighth grade. We find, however, that 7 boys and 3 girls had not completed this grade on entrance to the school. The superintendent stated to the survey that such pupils were admitted if they were mature, had been out of school some time, and were not likely to go back to the ordinary school. The annual catalog for 1915-16 states that such students will be permitted to enter on trial if in the judgment of the school authorities they are mature enough to carry on the work successfully. The records of these ten pupils who gave their previous schooling as less than eighth grade are

\section{BOYS}

\begin{tabular}{|c|c|c|c|c|c|c|c|}
\hline 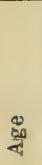 & ఊ̋ & 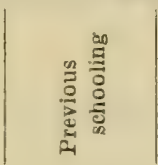 & 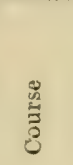 & 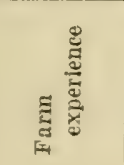 & 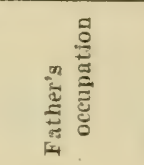 & 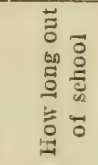 & 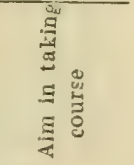 \\
\hline $1 \tilde{y}$ & Milwaukee & 7 th & $8 \mathrm{Ag}$. & $2 \mathrm{mos}$. & Machinist & No yrs. & Furmer \\
\hline 17 & West Allis & Not quite sth & $3 \mathrm{Ag}$. & Life & Gardener & No yrs. & Farmer \\
\hline 15 & Milwaukee & Tth & $3 \mathrm{Ag}$. & None & Bookkeeper & No yis. & Florist \\
\hline 18 & $\begin{array}{l}\text { Home for } \\
\text { Dep. }\end{array}$ & th & $3 \mathrm{Ag}$. & None & & $1 \mathrm{yr}$. & $\begin{array}{c}\text { Hortic. \& } \\
\text { Floral }\end{array}$ \\
\hline 16 & Wauwatosa & ith & $3 \mathrm{Ag}$. & Indef. & Carpenter & 6 mos. & $\begin{array}{l}\text { To better } \\
\text { education }\end{array}$ \\
\hline 18 & Milwaukee & 6th & $3 \mathrm{Ag}$. & 1 summer & & 5 yrs. & Farmer \\
\hline 14 & Milwaukee & 7 th & $3 \mathrm{Ag}$. & None & $\begin{array}{l}\text { Assembler } \\
\text { of trucks }\end{array}$ & No yrs. & $\begin{array}{c}\text { Practical } \\
\text { farmer }\end{array}$ \\
\hline
\end{tabular}

GIRLS

\begin{tabular}{|c|c|c|c|c|c|c|c|}
\hline 14 & Milwaukee & 6th & 3 D.S. & & Butcher & No yrs. & Householit \\
\hline 16 & Brookfleld & Not quite sth & $3 \mathrm{Ag}$. & Life & Farmer & Since June & \\
\hline 17 & Brookfield & Not quite 8th & 3' D.S. & Life & Farmer & $3 \mathrm{yrs}$. & \\
\hline
\end{tabular}

Four of the boys and one of the girls state that they had not been out of school at all. Four are scarcely above eighth grade age. The question here is not as to whether or not people of this training should be excluded by law. It is very probable that there are many cases where it would be almost an injustice to keep out certain applicants for this reason. But so long as the law requires eighth grade graduation there should be a very good justification for admitting pupils without it. Disregard of the state law might endanger the allowance of state aid. 
Farm experience of boys

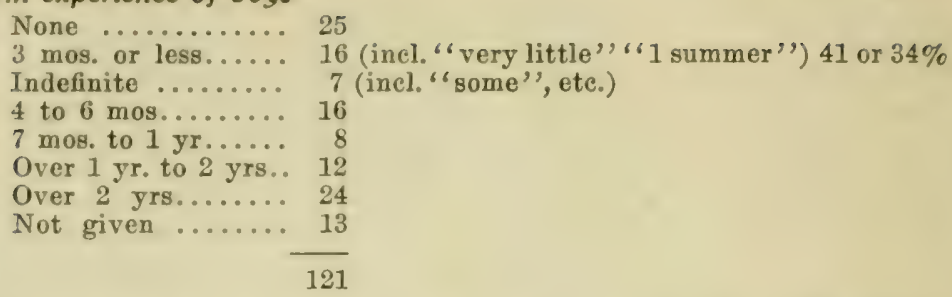

41 , or $34 \%$, have no or practically no farm experience. $36(30 ; i)$ have had over one year of experience. This latter percentage probabiy represents quite closely the percentage of farm boys. If anything the 24 $(20 \%)$ with over two years' experience would be nearer.

\section{Father's Occupation (Boys)}

The list is very extended but many occupations are closely related. The more numerous are

Farmer, 14

Carpenter and contractor, 5

Storekeeper, 5

Liquor dealer, 5

Salesman, 4

Machinist, 3

Cigarmaker, 3

Among the remainder with only one or two representatives each arefoundry superintendent, structural iron worker, decorator, marble polisher, millwright, gardener, clerk, engineer, wagon trimmer, blacksmith, railroad man, fireman, teacher, tilelayer, real estate, bookkeeper, peddler, factory superintendent, sexton, tailor, rural mail carrier, etc., all of the same general nature. For the girls the list runs along the same lines with the farmer predominating.

It appears from this list that the school is not a place where mainly children of the well-to-do go. In fact, it is the children of the workers and of the middle class who make up the entire enrollment. It is again shown here that it is not a school of farm boys but rather of city boys who for one reason or another desire the training the agricultural school gives.

\section{Length of Time out of School}

53 boys and 13 girls did not fill out the blank asking for this information. Of the remainder 22 boys and 14 girls said since June, or vacation, or three to four months; 18 boys and 2 girls had been out 
from four months to one year; 10 boys and 11 girls had been out over one year; 18 boys and four girls answered "none".

\section{Purpose in Caming to the School}

43 boys did not answer

47 said to be a farmer

20 to go into some kind of agricultural work (kind usually stated)

3 to prepare for the university

3 for practical use

1 for general preparation

1 to prepare for pharmacy

1 to prepare for engineer

2 to better education

23 girls did not answer

1 to prepare for college

3 for professional purposes

4 for dressmaking, millinery, nursing

13 more efficent housekeeping, D. S. training, to make living, to plan and design a home, etc.

As is to be expected in a school of this kind the boys have in mind some kind of agricultural work as their future occupation, and the girls either intend to prepare for better housekeeping in their own homes or for such work outside the home. It is noticeable that only a small percentage are preparing for college. Since the school is accredited to the university it is probable that a larger number may go there if they find it possible.

\section{Credits and Hours of Work}

Students are expected to take from 16 to 20 credits per term. This requires a little less than 30 periods per week. The actual number of periods for three year agricultural students averages 28 . In the four year course the average is 26 periods.

\section{Failures and Promotions}

107 boys received credit for 1620 courses in 1914-15. These same boys failed in 66 courses. The percentage of failures in tota! courses was 4 . This does not include incompletes and conditions, nor 
the work of those who dropped out without completing their work. Of the 66 failures 8 boys received 35 .

$2 \mathrm{i}$ girls received credit in 267 courses, and failed in 12 courses, the percentage is again 4 . Three of the girls received 10 of the failures. The ratio between failures and promotions is the same for the boys and the girls. This is unusual, for in Wisconsin high schools girls fail less than boys as a general rule. The percentage of failures is somewhat less than that in high schools of the state.

\section{Enrollment and Attendance}

For the year 1914-15 the total enrollment was 191. The enrollment cards now available for the present year show a total of 165 . This does not include short or special courses or summer course. The average daily attendance for 1914-15 was 118. The average daily attendance for the 1 st term in 1915-16 was 130 , but this is probably larger than the total for the year since about 40 students dropped out at the end of the second term to go to work.

For 1912-13, the first year of operation, the enrollment was 243 and the average daily attendance 146; for 1913-14 the enrollment was 206 and the average daily attendance 128. There has been a constant falling off from the high mark attained the first year.

The average daily attendance is determined by adding the total days attenced in each of the various courses-regular and special - and dividing by the number of days in the term. This is done each term. The three terms are added together and divided by three to find the yearly arerage. 


\section{CHAPTER VII}

\section{GRADUATES}

30 pupils have graduated from the school since its organization, 8 in 1914 and 22 in 1915. The superintendent of the school has piepared from his personal knowledge a list of their present positions. No records are kept.

1914 class
8 Boys - 1 with father in meat business
I on own farm in Washburn County
$I$ in milk business in city
1 on own farm in Illinois
I attending trade school
3 Girls-2 married
1 at home

1915 class

19 Boys-1 back in school preparing for Stout Institute

I on a Guernsey farm in Waukesha County

1 on his father's dairy farm

1 on

1 herdsman _......... farm, Wauwatosa

1 back in school

1 _...... poultry farm, West Allis

1 cow testing for the University

1 association cow testing

1 in partnership with brother in California

1 with American Appraisal Co., Milwaukee

1 on ......... farm last summer. Now back in school preparing for the University

$I$ at Marquette taking medicine

1 herdsman, insane hospital farm

1 on father's farm, town of Granville 


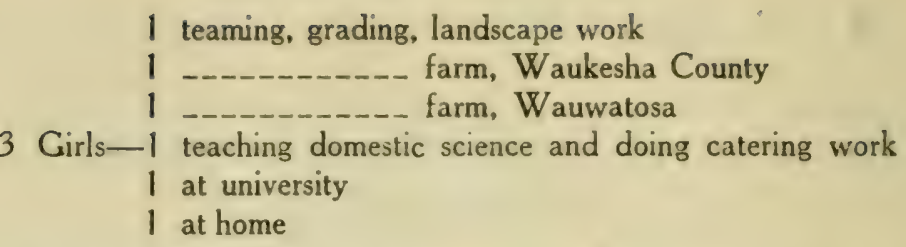

15 of the 24 boys are now doing some kind of agricultural work 9 are back in school or doing other kinds or unknown kinds of work

13, not including those in school, are in Milwaukee County

1 , of 6 , girls is teaching

2 are married

2 are at home

1 is at the university

4 are in Milwaukee County

A careful record of the graduates should be kept showing positions, salaries, further school work, and any other items of interest. What becomes of the pupils who have left school is an important matter. They should be kept in contact with the school. If they believe that the training they have received is useful they should be encouraged to get others to go. They are in a position to teach communities to make greater use of the facilities of the school thru meetings, correspondence, help in problems, and in any other matters where expert help can assist.

The graduate in his turn, if he is reached by the activities of the school will try to help the county realize to the fullest extent returns on the investment. The graduates and their work are only one of the products expected of a school of this type, but they are an important one, and can be made a very efficient means of developing the other products. 


\section{CHAPTER VIII}

\section{COURSES OF STUDY}

\section{The Three and Four $Y$ ear Courses}

The county schools of agriculture were originally organized to give instruction in agriculture and domestic science to boys and girls who did not intend to go to college. The courses were planned to last fo: two years and they were not intended to articulate with those of any other institution. Little of the purely academic work was given. The schools were vocational schools, teaching the subject matter necessary for the farming and home vocations with no regard to what the rest of the school system might demand.

This independent position is now being abandoned. The Milwaukee County School has not gone so far as some of the others. It stili maintains three year courses which do not prepare for college, and in which a majority of the regular students are enrolled, but it has established four year courses which add to the three year courses sufficient academic work to admit to the university of Wisconsin. The school is now on the accredited list and is subject to the same rules of the university as apply to other secondary schools in this list.

The work of the three year agricultural course includes science. agronomy, farm mechanics, botany, dairying, soils, poultry, hosticu?ture, animal husbandry, farm accounting, farm management, economiz entomology, some practical English, music, civics, American History, bee culture.

The four year course adds one year of algebra, one year of medieval and modern history, one half year of geology, one half year of commercial geography, one year of geometry, one half year of rural economics, one half year of arithmetic, one half year of elementary economics, and increases English to three years. The subject of Latin is not listed in the catalog but was given in the second term of this year as extra work to a class of seven boys who petitioned for it.

All of the subjects required in the four year course and not in the three are for the sake of meeting university requirements. The school is adjusting itself to the university. Three out of 121 boys declare 
their intention of going to the university. This does not mean that only three are taking the four year course, but it means that only three are taking the work with the purpose in view for which the new subjects were selected. To the remainder it makes no difference whether when they graduate they are entitled to enter the university or not. (The exception is, of course, the boy who may change his mind later, but this works both ways. Moreover, only one of the twenty-four boys who have graduated has the intention of going to the university. He graduated from the three year course and is back for the fourth year.)

On this showing the questions which arise are-

1. Shall the school be made an agriculture and domestic science high school?

2. Granting that a four year course should be given, are the subjects offered for the additional year the most useful that could be found?

3. Would they be given were it not for university requirements?

4. Does the number of students who intend to go to the university justify requiring all others in the four year course to take work which may not be most useful to them?

The pupil who graduates from a county school of agriculture and domestic economy or from a high school agricultural course has a much greater training in this work than the ordinary student entering the college of agriculture or the department of domestic economy at the university. The student entering agriculture at the university after four years at the county school will either have to duplicate work, take work other than agriculture, or actually be doing junior work when he is enrolled as a freshman. If there are many such, adjustments of curricula will have to be made. If graduates enter other departments they will not be so well prepared as the regular high school student and will lack language requirements. Moreover, their specialized agricultural training will not be of much value to them. Thus the attempt to articulate with the university seems to present considerable inevitable difficulties.

If the four year course is to be given in these schools, are the subjects in the extra year above the original course especially adapted to the pupils in the schools? Some of the additional courses can undoubtedly be made of practical value. In others, the advantage is not so apparent. It is said that a broad training and a wide foundation is necessary in any course, even a very technical one. The question remains as to whether this school is to be an agricultural high school or a school of agriculture giving training in agriculture without regard to the requirements of other institutions. 
Before the four year course was established at the Milwaukee County school, arrangements were occasionally made for pupils to take desired academic work in the Wauwatosa high school. Would not a plan whereby pupils could take all their academic work in the regular high schools be feasible? Arrangements could be made for Wauwatosa pupils to take such work for one year in the Wauwatosa High School, for Milwaukee pupils in the Milwaukee High Schools, etc. Or pupils might spend a small part of their regular time in the Wauwatosa High School. This would absolve the requirements for a high school diploma admitting to the university. The cost of instruction in high schools is less than that in the county agricultural school and a saving would be effected. Such a plan would require an understanding and a method of co-ordination between the county school and the other schools concerned.

A common criticism of the agricultural schools is that their courses lack in content, that there is insufficient material to fill the large number of courses and make them "meaty." If this is true of the Milwaukee County School there could have been no excuse for a three year course, to say nothing of a four. The truth of this matter, however, can only be determined by months of careful classroom observation and a thoro study of the content of each course. It is recommended that the board of administration take steps to learn if this emptiness exists in the subjects offered. If it does it should be eliminated by combination of subjects, by shortening the course, or by more intensive work.

The argument against the four year course briefly is:

The effort to make a high school out of the county agricultural school is a perversion of its function. High schools should teach agriculture and should prepare for the university. For the boy who intends to continue agricultural work at the university the high school work is sufficient, or can be made so without cutting too much into other subjects. The county agricultural school is for the boy who wants agriculture but does not want to go, or cannot afford to go, to the university, or to take the previous work required for university entrance. $\mathrm{He}$ wants to substitute the county agricultural school for the university. To make him substitute it for high school instead is to defeat his ends and the ends of the school. If suitable and sufficient work can be given in two years there should be a two year course. If four years are necessary there should be a four year course, but it should be a four year course in agriculture.

This argument applies equally to domestic science.

The argument in favor of the four year course is that it offers the same work as is offered in the three year course with the addition of a few 
subjects which make it possible to enter the university. A pupil can finish the three year course and then if he wishes to go on he can come back to the school for one year and get the necessary work. If this incentive is not added pupils tend to drop out before they have finished the work in the other courses. Every school should give such preparation that when the course is completed the graduate is able to go on to some other school if he desires. This can be done in the Milwaukee County school without in any way lessening the effectiveness of the shorter courses.

\section{Other courses}

In addition to the three and four year courses there is a projected short course covering the period from November 20th to April 1st for two years, which will be complete in itself or will give credit of one year toward any regular course. This course is just being worked out and it is planned to announce it for the first time in the next catalog. It includes

Ist term
Cereal Crops
Elementary Dairying
Carpentry
Elementary Poultry
Fruit Growing

Dairy Cattle

Soil Fertility

Farm Management

Farm Accounting

Blacksmithing

Insects

\section{FIRST YEAR}

2nd term
Forage Crops
Dairy Manufacture
Carpentry
Poultry Practise
Vegetable Gardening

SECOND YEAR

Stock Feeding

Soil Management

Drainage

Farm Accounting

Blacksmithing

Civics

Such a course ought to give good solid instruction, and should meet the requirements of many boys who cannot attend the full year.

(Short courses are considered as extension work and will be treated under that head).

\section{A Suggested New Course}

In order to give more fully practical farm training under the direction of the school it is suggested that a course be offered which shall be co-extensive with the agricultural year, say from March 1st to November 1st. (For a fuller discussion of this see Chapter XII-The School Farm). 


\section{CHAPTER IX}

\section{TEACHING STAFF}

The teaching staff of the school consists of the superintendent and thirteen instructors, ten of whom are in agriculture and three in domestic science. All of the instructors are men except those in domestic science.

\section{Training}

7 of the 14 members hold the degree of Bachelor of Science or Bachelor of Science in Agriculture, and one of these has in addition his Master of Science degree. Three have the Bachelor of Arts degree. Of these three none teach agricultural subjects. Three are graduates of Stout Institute, two of whom teach domestic science and the other Farm Mechanics. One has the degree of Master of Philosophy.

\section{Salaries}

Superintendent

Instructors

one at

2,200

one at

2,000

one at

1,820

one at

1,860

one at

1,700

two at

1,200

one at

1,100

one at

1,000

950

900

744

one at

$* 180$

one at $4 \mathrm{mo}-1 / 2$ time

one at

1,200

* per term of employment 
These'salaries are much higher than those paid for ordinary secondary school education. Agricultural teachers everywhere in such institutions have a higher rate of pay than teachers of academic subjects, but even considering this the rates at the Milwaukee school are higher. This is true in academic subjects as well as in agriculture. For the salaries paid the teaching should be of the best.

\section{Hours of Instruction}

Not including the superintendent, who has five periods per week of teaching, instructors have class periods as follows:

\begin{tabular}{|c|c|c|c|c|}
\hline one has & 10 & & & $\mathrm{ee}$ \\
\hline one has & 18 & , & ", & \\
\hline ne has & 19 & " & $"$ & \\
\hline ro have & 21 & " & ," & \\
\hline o have & 22 & " & ", & \\
\hline one has & 24 & " & " & \\
\hline one has & 25 & ", & " & ", \\
\hline one has & 26 & ", & $"$ & " \\
\hline one has & 29 & ", & $"$ & " \\
\hline e has & 30 & $"$ & " & \\
\hline has & 31 & " & " & \\
\hline
\end{tabular}

Periods are forty minutes each with a five minute intermission. In addition instructors do extension work, prepare lessons, correct papers, do farm work connected with the school, etc. The amount of this has never been determined. An attempt on the part of the survey to get this information from faculty members themselves was unsuccessful. The superintendent estimated that the men spent on the average seven hours a day at the school. This does not include Saturday when there are no classes. The amount of class work compares favorably with that done in other secondary schools. The amount of additional work determines largely how much more or less faculty members might be expected to do, and information on this is not available. 


\section{CHAPTER $X$}

\section{TEACHING}

This report on teaching is based on actual classroom observations and study of courses. While it would have been desirable to see more classe;, the results here given are in no way less valuable because the number of visits was limited.

18 classes were visited

Reports will tell only what occurred in those classes

Names of classes will be given

No class report is to be considered as a judgment on the teaching ability of the instructor concerned. Cood points or bad points observed are to be taken as examples of methods or practices which are used. Whether they occur seldom or often does not alter the important fact which is that they do occur. The defects pointed out should be discovered and eliminated wherever they exist. The good points should be encouraged and made general.

\section{Civics}

Seven boys constituted the class, and these boys sat at the back of the room. Effort was made to apply the work to the actual lives and experiences of the boys by specific questions as - "Do you and I pay direct taxes?" "Is the tax on an automobile direct or indirect?" The instructor invariably called on the student before asking the question which immediately lessened the attention on the part of the pupils not called on. In one case only two of the boys seemed to be listening and one of these when called on was not sure what he was to recite about. The instructor kept his book open before him and followed the text. This killed free and voluntary discussion. He referred to the text for questions and when a boy did not answer a question he read to him from the book. An interesting and definite assignment was given as part of the next lesson: "Find out how much income tax you will have to pay when you have a $\$ 20,000$ job. If married? If a single man?" 
Civics, especially when made part of the daily lives of the pupils, is a subject which arouses much interest in a class of boys. The instructor in this class seemed to know how he wanted to conduct the class; he wanted the boys to take an active part. He had their good will but could not keep up the interest. The greater part of the interest shown seemed due to the subject rather than to the teacher. It should be mentioned that the subject is one which is outside of the instructor's regular line of work.

\section{Soil Fertility}

16 members were present.

The outstanding feature of this recitation was lack of discipline. The instructor stood at the middle seat of the fourth row while the pupils all sat in the last four rows. The observer reported on this class in part: "The instructor might just as well have been at the front of the room, for his presence was disregarded during the class disturbances that took place. Not only were notes passed, but a note book with them was deliberately thrown under the seats from the first boy to the last boy. No hesitation was shown in speaking aloud. * * A few were trying to behave. $\% \%$ One of the noisiest, who had been sent to the front row, turned around and entertained the class more than ever from that vantage point. The instructor kept his text open and referred to it often. He kept down discussion by dragging pupils back to the 'next paragraph.'

It is doubtful if the pupils receive much benefit from a class where discipline is so bad a's it was in this class.

Soils

This class was made up of eight boys.

The period was spent out of doors laying out plots. The instructor did most of the work himself, especially with the instruments. The boys learned the names and uses of these only by asking. They were anxious to know how to use them, but they were told that the time was too short and that they could learn at a later period. The period was in effect a demonstration of the use of unnamed instruments, which the pupils did not learn enough about to understand. Their enthusiasm seemed to be suppressed rather than encouraged.

\section{Food Study}

Eleven girls were in this class.

The subject of the recitation was starch. The pupils and teacher seemed to have the subject well in hand, but the class was of the monotonous type. A series of çuestions were faithfully answered by each 
girl in turn. The instructor kept her note book open before her. She usually asked the question before naming the pupil, but there were several exceptions to this. No effort was made to correlate the work with that in botany and physiology. These classes and the laboratory were isolated things.

\section{Home Management}

One student.

The pupil had planned a home and was given two sums, one large and one small, with which to make two plans for furnishing it. The teacher sat beside the pupil and criticised the plans. The pupil had two catalogs from which to select the home equipment. These the teacher had gotten for her.

\section{Horticulture}

\section{7 boys}

2 periods-one laboratory and one outdoor section.

The laboratory section was making grafts. Both instructor and pupils were much interested. The instructor was kept very busy. The pupils made about 20 grafts each, but they did not know what plants they were grafting. Neither did they know how the string used was prepared. The instructor said that he would plant the grafts to see how many would grow. He did not say that he would let the boys plant them.

The outdoor section was spent in checking and planting trees. Each boy had something to do. All were interested. The instructor was full of life and kept all interested. The class showed good spirit.

\section{English}

Class of 13 boys and 2 girls.

The first part of the lesson was given over to a written spelling lesson. The papers were exchanged and the instructor spelled the words while the pupils marked the papers. A story read the previous day was then told by one of the girls. She told it well. Next some time was spent on reading from "Myths of Greece and Rome." The pupils were closely questioned about what they had read. One boy had trouble in remembering, but after a second reading was able to tell without stumbling. Another boy was interrupted because he put in a word. This distracted his attention. The instructor never called on listeners to correct mistakes.

Throughout the period there was good order. The instructor has much personality and he has the respect of the children. 


\section{Ancient History}

13 boys and 2 girls were in this class

This period was given over to a written quiz.

Five questions were asked. None of the questions applied or asked for an application of any event in ancient history to modern conditions. It represented the kind of history teaching which encourages boys and girls to exercise memory rather than reason.

A large amount of cheating would seem to indicate that the class was not well prepared for the examination. While the instructor was writing the questions one pupil opened his book to get some notes. Two others looked at each other's papers and passed notes.

One boy slipped his paper nearer his neighbor so that this boy might see what he had written. At least five others looked at each others papers again and again. The instructor was in the room, occupied with the reading of a book.

\section{Algebra}

A written quiz was given the first day. On the second the work was gone over. The instructor told the class that they had done very poorly. He spent the period in a thorough explanation of quadratic equations, the subject matter of the test. The instructor frequently asked if there were any questions, and twice pupils asked them. On one occasion the instructor asked if there were any questions and added that there certainly should be none on that part. This did not encourage any one to ask. On the first day in particular the instructor spoke in a drawling undertone. There was much more life and spirit the second day. The students were given the papers to take home and correct. This would make them finally get the work done correctly. The instructor used the quiz not only as a test of what the pupils knew of the subject but as a teaching means.

\section{Botany}

9 boys and three girls constituted this class

The first period was used for a field trip to a nearby grove. The purpose of the lesson was to teach trees in their winter aspect. The instructor pointed out and described the trees. A student was called on occasionally to name a tree of a kind just described. Two of ten pupils gave the correct name the first time. The instructor tried to teach pupils to recognize the following trees-white oak, red oak, soft maple. hard maple, Carolina poplar, prunus serotina, ironwood, bass wood, white ash. It is possible that any group of people would have diffculty in learning to remember all these in an hour, especially when the leaves were not out, and the trees were so tall that the bud arrangement 
could not be easily seen. Twigs were gathered and these were to be carefully drawn and labeled in the laboratory at the next period. Just why time should be spent in drawing twigs in the laboratory when the whole woods was available for actual daily study did not appear. The pupils did not seem to learn to know the trees. As a matter of method the question may be asked-is it well to teach the barks of a group of trees one day, the leaves on another, etc., in showing how to know trees; or is it better to teach all about one tree one day, and about another at a different time? In order to remember the names of the twigs which she was to draw, one girl put soft maple in one pocket and hard maple in another. This did not help much for she soon forgot which pocket had the soft and which the hard.

The next day in class this field trip was never mentioned. The class recited about palms and cocoanut trees that they had read about in the text. The recitation and the laboratory were disconnected things. The work was not connected up for the girls with their practical work in domestic science.

The first question in the recitation was to name the four large groups into which plants were divided. It took two pupils to give thallophytes, bryophites, pteridophytes, and spermatophytes. When pupils stumbled over the pronunciation of these or other long words the instructor helped but he did not give their derivation or anything else which might have helped the pupils to understand and remember them. After a discussion of monocotyledons and dicotyledons the instructor drew and labeled illustrations on the board. A little later a girl asked if maple seed was a dicotyledon. The maple was one of the illustrations the instructor had previously drawn and labelled. He answered "Yes" to this and other questions which might with profit have been discussed by other members of the class.

This instructor seemed to work hard. To some extent he kept the interest of the pupils. He never discouraged them and answered their questions even though at first they seemed of no value.

\section{Veterinary Science}

\section{5 present}

This class was made up of the more mature students. The first few minutes were given over to review of tuberculosis. The instructor showed the class an affected gland. Then he began to lecture. One student wanted to ask a question, but was asked by the instructor not to interrupt him while he was talking. As the instructor talked the rest of the period not another boy said a word. The instructor lectured slowly, stopping now and then to give students time to get what he said fully in their note books. The lecture method is usually de- 
fended on the grounds that large classes make it necessary. How would lecturing to a class of five students be defended? Discussion was discouraged by the instructor's asking the pupils not to interrupt him. It was not an inspiring recitation. The instructor was very serious both in manner and appearance. The class was interested especially during the review at the beginning of the period.

\section{Practices to be Discouraged}

Book open before instructor and referring to it for questions and answers

Lack of discipline

Calling on pupil before asking question

Preventing discussion on part of pupils by dragging them back to the text or answering questions which other pupils could answer

Discouraging questioning on the part of pupils

Instructors doing most of the work

Lack of explanation by instructor of work he is doing

Lack of correlation between laboratory and class work, and between different classes

Not telling pupils what they are doing and why

Not permitting students to go through whole process from beginning to end

Distracting attention of pupils by interruptions

Lack of respect for teacher on part of pupils

Cheating by pupils

Indistinct speech on part of teacher and pupils

Overmuch memory work and insufficient reasoning work by pupils Lecturing to small classes

Each of these defects is illustrated in the reports on observations. In nearly every case there were redeeming features.

The illustrations show that much careful supervision is needed. The pupils are of an age which demands good teaching. Interesting subject matter will cause the pupil to derive some value from even the poorest teaching, but pupils between the ages of 13 and 20 are not of the maturity which will give them the ability to learn more than a smattering of any subject without expert assistance on the part of the instructor. While the base used is not large enough to say that the teaching of any one instructor is either good or bad as a whole, it is possible to say that in certain of the classes visited the benefit to the pupil was very small. The lacks shown were apparently not due to deficient knowledge by the teacher of the subject matter to be taught, but 
rather to defective methods, which might have come either from carelessness or from lack of knowledge of teaching methods. If due to carelessness all that is necessary is to arouse the instructor out of his rut, remind him of the exacting demands of teaching, start him to thinking on methods of making his teaching a means of giving the pupils interest, knowledge, and a desire to work. Self-analysis by each instructor will show personal reasons for defects; study of work by the teacher himself will show where the faults in the teaching lie.

For the new teacher, or the teacher who is not familiar with teaching methods, assistance on the part of supervisors is necessary. Helpful suggestions, based on study of the teacher's peculiarities and on visits to the classroom, will help do away with many shortcomings. The man whose faults are glaring, who will make no effort to correct them, or who is not suited to the kind of work he is doing, has no place in a school of this or any other kind. It should be noted that one instructor, whose work appeared on the day visited to be very bad, will not return next year.

\section{Supervision of Instruction}

The superintendent of the school says that he aims to visit a ciass of each instructor once a week. This would require thirteen periods of supervision a week. No record of the number of visits is kept, so it is not possible to tell how nearly this standard is approached. The amount of visiting by superior officers to their assistants is not known. The amount of real assistance which those in charge can give their assistants depends on how purposeful the visits and conferences are. Assistants can also to some extent help their superiors. Of the ten teachers whose classes were visited, only four were not in charge of departments. Some of the assistants showed work which was better than that of some department heads. On the other hand, the work of one assistant showed much lack of experience, while that of the man in charge was among the best seen.

The solution seems to be that there should be a system of intervisiting. Not only should the superintendent visit the classes of all teachers, but department heads should visit their assistants, and assistants should see the work of those in charge. The assistants could see results due to better methods and learn to avoid faults which they observe. It is less difficult to learn by seeing teaching faults and virtues in others than in the individual himself. The superintendent and department heads could point out to instructors where their weak points are. They could demonstrate for a period if they felt that this would help. Each instructor would have the opportunity to get away from his own limited field, and see in others the things that in his own work he had perhaps 
from very nearness overlooked. The system would tend to make each man analyze his own work.

The presence of the defects observed in classroom work indicates one or more of four things in regard to the supervision of the superintendent

1. He visits for the purpose of seeing only and not for the purpose of helping the instructor.

2. He does not follow up his visits with conferences or suggestions.

3. Pupils, all of whom know the superintendent, make especial efforts at the time of his visits.

4. The instructor is especially careful at the time of the visits.

It is undoubtedly true that the instructors and pupils try to be at their best on the occasion of the visits of the superintendent. It is also true that the defects are not all of the kind that can be put on and oif at will. Some of them will occur no matter who is present. Those that can be eliminated when the superintendent is present should be eliminated by the instructor at all times. Those that can not be so done away with should be noticed by the superintendent and he should assist in remedying them. Present supervision does not seem to be effective. No doubt the superintendent knows in general who are the best and who are the poorest teachers. Does he know specific defects and doss he try to overcome them? Is his supervision a real thing or is it merely for the purpose of fulfilling the requirements of the school? 


\section{CHAPTER XI}

\section{EXTENSION}

Work done

In two records in the office of the school are the extension activities of the school listed. One is a typewritten statement entitled "Some Facts Concerning the Agricultural School" and the other is a copy of a letter of the superintendent to the board of administration. The letter contains all the extension activities mentioned in the statement and three additional items. From these two sources the activities are

Enroll.

1. Special 8th grade work at the school in co-operation with the Hawley Road and 36th St. School_..._.... 13

2. Special millinery classes at the school_......... 52

3. Special sewing classes at the school_._._._._._. 35

4. Special cooking classes at the school_..._........ 30

5. Saturday courses for Milwaukee County rural school teachers, at the school_._._._. 22

6. Course at the Milwaukee Public Library_....._._. 75

7. Lectures at social centers in various parts of the county _.- 100

8. Farmers' course at the school

9. Poultry show at the school

10. Calf raising contest

11. Corn and barley contest

12. Corn exhibit at school

13. Exhibit at state fair

14. Vacant lot gardening within city limits of Milwaukee

15. Direct aid to farmers in the county

16. All other efforts made in the direction of advertising the institution and aiding the community not only to increase attendance but to acquaint the community with the benefits that may be 'secured by co-operating with the school

17. Classes for children from the Home for Dependent Children 
Appointments Shonen for the First Four Months of 1916 by the Superintendent's Calendar

Jan. 7-Mr. Perry and Mr. Phillips-Greenfield Ave. School

Jan. 21-Mr. Perry and Mr. Sievers-Browning School

Feb. 4-Mr. Siever's and Mr. Adams-Tippecanoe School

Feb. 11-Mr. Perry and Mr. Sieverj-Fox Point School

Feb. 12-Mr. Holzinger-N. Milwaukee School

Feb. 18-Mr. Bartholomew-Ludington School

Feb. 28-Mr. Sievers-Woodlawn School

Mar. 7-Mr. Perry and Mr. Roehl-Lincoln School

Mar. 11-Mr. Sievers and Mr. Perry-Mapletree School

Mar. 17-Mr. Sievers and Mr. Perry-Fischer School

Mar. 31-Mr. Sievers and Mr. Pelry-Mapletree School

Apr. 10_-_McKinley School

Apr. 14-Mr. Perry and Mr. Sievers-Ardenwood School

Apr. 28-Mr. Perry and Mr. Sievers-Burleigh St. School

A brief general statement of extension work is given in the annual catalog.

All short courses are considered extension work. This includes the summer session. Tho the school authorities do not list it, it is so considered by them for most purposes.

Nowhere is there to be found a complete detailed statement of the work done in extension, of the time spent, or of the cost.

No records of any kind are kept for any of the work except the courses at the school.

The report here made is based on course records, conferences, letters, statements, bulletins, and such other scattered material as could be secured.

The eighth grade class consists of thirteen girls who come over once a week for cooking and sewing.

The special millinery, sewing and cooking classes are composed of city women who come out one afternoon a week during the spring and fall terms to receive special instruction. The classes aim to give practical work along these lines. They are adapted to those who do not wish to take a complete course in the school.

The Saturday course for rural school teacher's is designed to give instruction to these teachers which will be of benefit to them in their work and at the same time help the school. It continues for eight Saturdays.

The course at the Milwaukee Public Library consists of a series of popular lectures on agricultural subjects for city people interested in agriculture. The lectures are given twice a week for eight weeks. Among the subjects are 
Wisconsin Geology in Respect to Soil Formation

Planning a Back Yard Garden

The Helpful Hen

Hotbed Construction and Management

Best Results in Poultry Feeding

Some Vegetables Worth While

Raising the Dairy Calf

Life of the Honey Bee

The Herd Bull

Bush Fruits

City and Country Bee Keeping

Back Lot Poultry Keeping

Managing the Dairy Herd

Production and Composition of Milk

Two lectures are given each evening, making a total of thirty-two for the course.

The farmers' course at the school lasts for three days and consists of lectures, demonstrations, and meetings. In connection with it are the poultry show, calf raising contest, corn and barley contest, and the crop exhibit.

These various courses reach about 500 people according to the enrollments given. Some attend only a few lectures and some attend for a course.

The school statement concerning direct aid to farmers in the county, reads: "This item alone is valued at not less than $\$ 2,000$ a year in counties where a county representative is employed." County representatives give their full time to the work. The superintendent of the school estimated for the survey that it would take the time of one man for two days a week to do the work done in this line by the school. On this basis this item should be estimated at $1 / 3$ of $\$ 2,000$ or $\$ 667$. This work consists of personal visits to farmers, advice on farm problems, help on silos, correspondence, etc. It is done by the various members of the faculty each of whom makes such visits and helps on such work as falls within his field.

40 children from the Home for Dependent Children, which is adjacent to the school, come three mornings a week for instruction in agriculture or domestic science.

Cost

It is not possible to get the exact cost of extension work because of the lack of records showing distribution of time, and of work done. From the basis of how much less the school would cost if there were 
no extension work, it is very low. No fewer instructors would be employed, except perhaps one in domestic science. The buildings and equipment would be the same. Some traveling expense would be done away with, as would a small amount for printing and postage. The total of these possible reductions would not amount to over $\$ 2,000$ and would probably be much less. This type of work can be carried on without much additional cost.

The superintendent estimates that extension work costs about $1 / 6$ of the total operating expenses of the school. Any figures which can be given must necessarily be estimates.

An analysis of the average daily attendance figures shows that about $1 / 6$ of the attendance is in special courses which come under extension. On this basis 1/6 of operating cost is chargeable to extension. The cost of the other work is too small to change this fraction, so $1 / 6$ of total operating cost is as near the actual extension cost as can be arrived at from the data available. This would give for the cost in 1914-15 $\$ 8,105.64$. The net cost, after subtracting $1 / 6$ of the $\$ 10,000$ returned by the school to the county, is $\$ 6,438.64$.

\section{Summary}

Extension work lacks organization. It is undeveloped. At present the s0-called extension consists in large part of special classes at the school. The real extension work consists of some lectures in the city, lectures at social centers, direct aid to farmers, and a short course for farmers with attendant contests and meetings.

Records should be kept showing costs, visits, time ipent, classes, lectures, calls, etc.

Separate accounts should be kept of all direct costs.

Recommendations for the furtherance and development of extension work are contained in the discussion in Chapter II. 


\section{CHAPTER XII}

\section{THE SCHOOL FARM}

\section{The Farm Proper}

The school farm consists of 206 acres. This includes campus, woodlots, and land used for other than farm purposes. The land was purchased at $\$ 350$ an acre thu's representing an investment of $\$ 72,100$ in addition to the buildings and equipment, which would add approximately $\$ 15,000$.

As stated in the 1915-16 catalog the school possesses "a full equipment of high class and improved farm machinery." This, according to the inventory, is valued at $\$ 3,091.57$.

About 15 acres are devoted to fruit raring and truck farming. The crop production of the farm aside from this in 1915 was

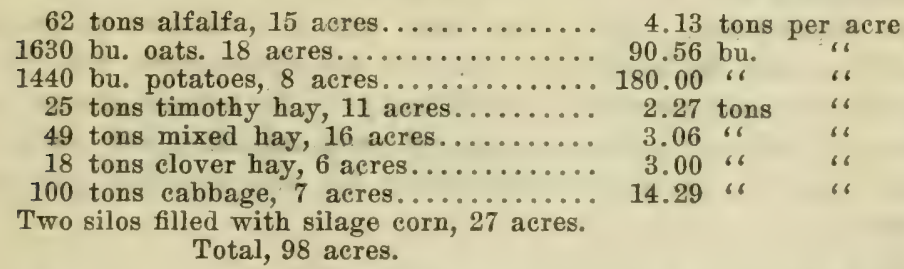

The orchard, truck farm, woodlots, and grounds used for buildings make up the remainder of the farm.

\section{Dairy}

The dairy equipment is very complete not only from the teaching standpoint but from the viewpoint of a dairy farm as well. The herd now numbers twenty-five in addition to the young stock on hand. (For detail see "Equipment", Chap. V.)

A statement of the school says:

"Its dairy herd (the school's) has been increased fifty per cent (time not given) and the production of this herd has averaged for the last two years 8,180 pounds per cow, while the average milk production of dairy cows in the State of Wisconsin is less than 5,000 pounds per cow." 
This looks like a very good record, but in order to give a perfectly fair and useful comparison the production of the school's cows should be compared with the production of cows of like grade in the state. Adding together the average production of cows of all kinds and comparing with the production of a high class herd merely shows what everybody knows-that high class herds produce more. It does not show whether the standard of production for that particular herd is high or low.

The dairy barn is a large building and is clean and well kept. The milk produced is certified milk. Most of the necessary feed is produced on the farm. A driveway leading to the hay loft is being planned, the work to be done by the pupils as part of their work in carpentry and concrete.

\section{Costs}

The school office does not have in easily available form records showing cost and returns of the farm and dairy. It has records, which, if summarized and collected would show this. The farm foreman keeps a record of each field, including records showing amount of time spent on each. If a man puts in one half-day on one field, an hour doing teaming for the school, and an hour in dairy work, and the rest of the day with the poultry, these records will show it. Costs are distributed in the same way. Both costs and returns are divided between departments. But these facts are not collected at present. Last December the bookkeeper's position was discontinued, and tho he said that the farm produced a profit last year, his records cannot show how much without a great amount of work collecting and analyzing detail. For the purposes of this study the superintendent gave estimates.

The estimates of the superintendent are

\section{Receipts}

Dairy and poultry produce............. \$4,800

Potatoes ............................. 1,260

Berries and fruit......................... 300

Hay ............................... 300

Miscellaneous ..................... 300

Expenses

$\$ 6,960$

Farm foreman ....................... \$\$ \$960

Men ........................ 1,500

Herdsman ............................ ${ }_{720}$

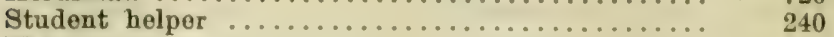

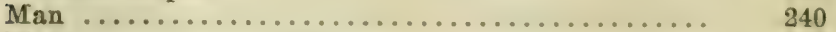

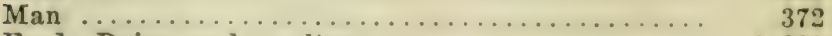

Feed-Dairy and poultry................. 1,200

Other ........................... 500 
Expenses include transfers from other departments. This shows a profit of $\$ 1,228$, an approximation. That actual facts were not available four months after the close of the year speaks badly both for the school records and the desire of the authorities to know. It should be noted before accepting the statement that the farm is running at a profit that no interest on investment is considered. A farmer could not afford to run the farm as the school runs it. The superintendent stated that the investment was not considered and could not be considered. He gave this illustration:

Suppose 50 bushels of oats were raised on one acre. At 40c a bushel this would bring $\$ 20.00$ Interest on the investment is $\$ 17.50$ $(\$ 350$ at $5 \%)$. Taxes, if it were private land, $\$ 1.00$, threshing $\$ 1.50$. This would take all of the $\$ 20.00$ leaving nothing for labor, seed, fertilizer, and other items.

For grain raising purposes it will be granted that the farm could not be made to pay, even tho the farm did raise 91 bushels of oats to the acre.

Interest on $\$ 70,000$ (200 acres at $\$ 350$ per acre) at $5 \%$ is $\$ 3,500.00$. This would wipe out over twice the profit estimated for last year.

The question which naturally follows is whether the school should try to raise grain. As a matter of fact it does not, as is shown by the table of $\mathbf{p}$.

\section{Can and Should the Farm be made a Paying Proposition?}

The location of the farm is such that a profit can only be made by very intensive farming such as truck gardening. The farm is primarily for purposes of instruction and this should always be kept in mind. The question then is-can the farm be made to pay and still fulfill its function as a teaching agency?

The pupils in the agricultural department of the school are ostensibly there to learn farming. They wish to know something about the various kinds of farming. Some are interested particularly in dairying, some in stock raising, some in grain farming, some in fruit farming, etc. But from the standpoint of Wisconsin agriculture most of them are not primarily interested in grain farming, and the school recognizes this and raises but little grain. It comes then to a question of whether truck gardening, dairying, fruit growing, etc., can be so done on the school farm as to teach successfully and still make money. This kind of farming is that used on farms of like location and value. Its ability to pay depends entirely on a correlation of the teaching function with profitable farming.

The school farm carries on each of these intensive activities to some 
extent. Dairy and poultry produce last year sold for $\$ 4,800$, potatoes $\$ 1,260$, berries and apples for $\$ 300$. There are certain factors that enter here which reduce the return.

1. Much, or most, of the produce is sold to other county institutions. These buy at a cost lower than the market price. E. g., the county Home for Dependent Children buys milk, which is certified and would ordinarily sell at $8 c$, for $51 / 2 c$; the school dormitory pays $5 \mathrm{c}$ for this milk.

2. The work is not done on a large scale.

3. Much of the time on the field and in the dairy is spent on work that the ordinary farm does not have, i. e., demonstration to pupils.

On the other hand there are certain advantages that other farms do not have:

1. Constant expert advice and service always at hand and in charge.

2. Free student labor.

3. Large equipment, and opportunity and facilities for trying out advanced methods and processes.

In the preceding discussion there have been indicated possible methods of increasing the farm productiveness.

1. A larger amount of truck gardening, fruit farming, etc.

2. Credit farm with the market price of produce sold to other departments and institutions.

3. Extend the idea of "learn to do by doing".

4. Make fuller use of the expert advice, service, and of equipment and facilities at hand.

On the first suggestion there can be little question. A truck farm efficiently conducted ought to pay.

The second suggestion does not mean that the county institutions should pay more for the milk and supplies they get from the school. It simply means that in figuring returns such supplies should be figured by the school at the price which the institutions would have had to pay elsewhere. These accounts, should, of course, be kept separate from the actual cash and transfer accounts. An extra column would take care of them. The advantage of this method would lie in helping to give the actual cost for each institution concerned. It would show to what extent one institution was in reality helping to support another. Such information would be of value in making up budgets.

Learning to do by doing is coming more and more to be an accepted method of teaching. It is taking the place of demonstration in many fields of study. It is generally called practical field or project work. Agriculture seems especially fitted for this method. Directed work in place of demonstration is a field for experimentation which will have an educational value aside from that given to the pupils first con- 
cerned. A direct application can be readily given. Milwaukee, as a large city, supports much truck gardening. At present a course in vegetable gardening is given at the school. The boys in the course are each given a plot $20 \times 25$ feet. This they must take care of till the end of the school year. The gardens are so arranged that after the pupils leave they can be cultivated with a cultivator. Would not the boys learn more about vegetables and more about large scale gardening, marketing of products, financial considerations, market needs and demands, etc., if they were required to put a little more time each day on a larger plot, not in individual parts, but worked in one large garden under the direction of the instructor? If the garden were then considered as a commercial proposition and the boys felt that they were part of the scheme and must make it pay, they would have a better training.

It has been argued that the best boys will not work more than is necessary for demonstration purposes, and that the boys who will are not the kind who are wanted to work on the farm. The answer to this is that the fault lies with the teacher and not with the boys. Boys were observed doing manual labor under the direction of a teacher and they seemed eager and glad to do it. Another discouraged the attempts of the pupils to do more. A teacher can inspire the boys with a liking for and interest in the work. Most boys have a natural interest in garden work, especially those who go to an agricultural school. If the boys are really interested in their work, if they want to know agriculture, they will not object to a little farm work.

In the dairy the boys do some of the work, but it is just while they are taking a certain dairy course. Here no saving is affected because most of the boys are inexperienced and they must be helped. When the students were left alone for a week, milk production fell greatly. This should not be true of older students. Why can not part of their work be to assist and direct the others? The boys who work in the dairy regularly are paid by the school.

This is an important question in agricultural education. If boys can be taught agriculture better by being placed in touch with and taking part in actual farm problems, there seems to be no reason why they should not be so taught. The system would be cheaper for the taxpayers, for the farm could be made to pay a part of the operating expenses of the school. It cannot be said without trial that such a system will not work in the Milwaukee school. It has never been tried. Only the most feeble attempts, under unfavorable conditions have been made: A strong attempt with a determination to use every possible resource is necessary to work out a plan that will succeed. That an effort be made is a just demand. To permit the farm to work at less than its maximum production is an economic waste which is unjustifiable unless it is defi- 
nitely shown that this waste is necessary to prevent greater waste in educational production. This has not yet been shown and until proof is given one way or another the school will always work under the suspicion of citizens that it is not using its opportunities in a fruitful way. If the boys really wish to know agriculture they will not object to more farm work. It is not expected that this extra work should take the place of the required farm experience. Even with the largest farm production, life at the school for the six hours a day would not approximate the life on an ordinary farm. It is this life with its variety of occupations and duties, its difficulties and limitations, that the boy wants in his actual farm experience.

The most important time of the year in agriculture is from March to November. During three of these months-the mid-summer months - the boys are not in school. Some of them are on farms, some are doing other work or no work. In order that the school should have the opportunity to teach the boys while they are getting practical experience in the time when that experience can best be gained, a course extending through the summer months would be most beneficial, if practical. Carried a point further, a school year extending from March to November, thus corresponding with the agricultural year, would permit the school to take the boys through an entire crop season. It would permit of carrying out the gardening and fruit projects completely. It would be a long step toward putting the farm on a paying basis.

Two important objections will be made.

1. Boys cannot be kept in school during the summer. Many of them must or will go out to work.

2. What will be done with the boys in the winter months?

The first objection will be sound for many boys. But for othersthose who do not have to work and those who can be made to see the advantage of staying in school-the plan will work. The course could be made very valuable to the boys, and they could be shown the ultimate benefit of staying in school through the summer. A fairly large enrollment might be built up.

The second objection has in mind the boys who would be out of school without work in the winter month's. This could be overcome by filling this period in with regular school work. A system whereby part of the boys at a time could take a week's vacation in the summer would permit this. Such an all-the-year-round school would tend to raise the summer enrollment, for it would lessen the total length of the course by one year.

One more consideration should enter into this problem of working the farm to more nearly its productive capacity. It is supposedly a model farm, a demonstration farm for the county. Yet if the farmer 
ran his farm on the basis of the school farm he would go inso bankruptcy. The school farm has model parts, small field's, plots, farm records, dairy plant, etc., but it is not a model whole. The farmer is impressed with a few details but not with the farm as a business. It is not a model after which he can pattern his farm. Specialized farmers can, indeed, learn but little, even from the details, because they are familiar with what is on the school farm from their own experience. To these the only benefit comes from such students of the school as they may employ and whose specialized training may help them on the specialized farm. Such pupils get to some extent, without the help of an instructor, what more extensive work with such assistance would have taught them much better and more quickly at school. 


\section{CHAPTER XIII}

\section{THE SCHOOL FINANCES}

\section{Financial Reports}

There are two chief items to be considered in studying the efficiency of any school. One is the work being done-quantity and quality. This we have taken up in the preceding chapters. The other is the cost. Poorly done work would be expensive at even a low cost. Work which may be very good might be considered as not worth while if the cost is excessive. It might be very beneficial to the average man to hear a world renowned symphony orchestra give a concert, but if he were asked to pay $\$ 25$ to hear it, the cost might conceivably outweigh the benefit. A city might like very much to buy land for a new park, but it is conceivable that the cost would be too high. So, too, Milwaukee county may want to teach agriculture and domestic science in a special school. It can and is doing so. But one of the questions which must be answered is whether the cost is low, reasonable, or excessive. If the work is poorly done and the price is low, it may be well to spend more for better work after attempt has been made to better work without increasing cost. If the work is poor at what would be reasonable cost for good work, the only remedy is to better work without increasing cost. If, again, the work is poor and the cost excessive, radical measures are necessary. Either both work must be made good and the cost at the same time lowered, or else the county cannot afford to continue the school. The last is also an alternative if the work is good and the cost excessive. The other alternative is to lower cost without injuring work, or to increase quality of work without increasing cost. If work is good and cost either low or reasonable there can be no real objection to the school if it fills a real need in the county. Attention can then be given to opportunities for bettering an already satisfactory institution.

The Milwaukee County school, together with all other such schools in the state, submits an annual report on enrollment, attendance, and finance to the state superintendent of public instruction. The Milwaukee school had been in operation for three years up to July, 1915. The reports for the three years are: 


\begin{tabular}{|c|c|c|c|}
\hline & $1912-13$ & $1913-14$ & $1914-15$ \\
\hline 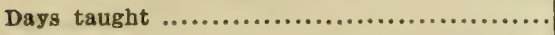 & 161 & 193 & 185 \\
\hline 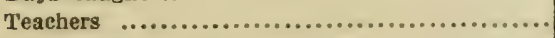 & 15 & 14 & 13 \\
\hline Earollment...$\ldots \ldots \ldots \ldots \ldots \ldots \ldots \ldots$ & 243 & 200 & 191 \\
\hline 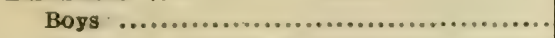 & 152 & 138 & 124 \\
\hline 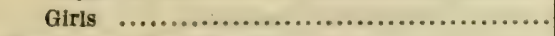 & $91^{2}$ & 68 & 67 \\
\hline 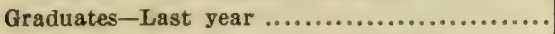 & 0 & 8 & 22 \\
\hline 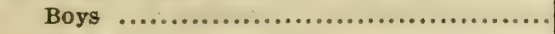 & 0 & 5 & 19 \\
\hline 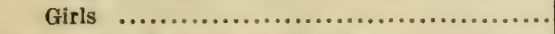 & 0 & 3 & 3 \\
\hline Graduates-Since organization ............... & $\mathbf{0}$ & 8 & 30 \\
\hline 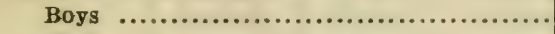 & 0 & 5 & 24 \\
\hline 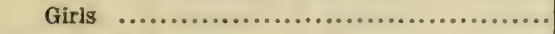 & 0 & 3 & 6 \\
\hline Average age: & & & . \\
\hline 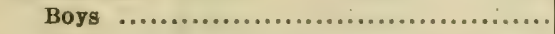 & $171 / 2$. & 18 & 18 \\
\hline 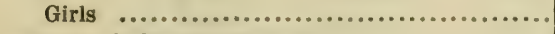 & 20 & 18 & 19 \\
\hline 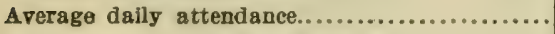 & 146. & 128 & 118 \\
\hline Adult specials (not included) .................. & 69 & $\begin{array}{l}2 \text { times per } \\
\text { wk., } 13 \\
\text { wks., } 50 \text {; } \\
\text { daily, one } \\
\text { wk., 150; } \\
\text { summer, } 2 \\
\text { wks., } 40\end{array}$ & $\cdots$ \\
\hline
\end{tabular}


FINANCIAL

\begin{tabular}{|c|c|c|c|c|}
\hline & $1912-13$ & $1913-14$ & 1914-15 & \multirow{36}{*}{$\begin{array}{l}\text { Remalnder } \\
\text { not } \\
\text { reapprop. } \\
\text { (In 1915-16 } \\
\text { appro.) }\end{array}$} \\
\hline Receipts & & & & \\
\hline Balance June $30 . . . . . . . . . . . .$. & a........ & $\$ 20,307.12$ & $\$ 5,751.39$ & \\
\hline 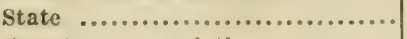 & n.......... & $8,000.00$ & $7,000.00$ & \\
\hline County appropriation ............ & $\$ 135,161.98 \dagger$ & $37,175.16$ & $45,281.50$ & \\
\hline 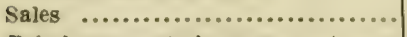 & $7,326.44$ & $10,638.28$ & $10,141.93$ & \\
\hline $\begin{array}{l}\text { Reimbursement for exp. not cov. } \\
\text { ered by appropriation............. }\end{array}$ & $9,145.18$ & & & \\
\hline \multirow[t]{2}{*}{ Tuition $\ldots . . . . . . . . . . . . . . . . . . . .}$. & n.............. & 136.00 & 522.00 & \\
\hline & $\$ 131,633,60$ & $\$ 76,256.56$ & $\$ 68,696.82$ & \\
\hline Expenditures & & & & \\
\hline Superintendent $\quad . . . . . . . . . . . .$. & $\$ 3,899.88$ & $\$ 2,319.74$ & $\$ 2,600.00$ & \\
\hline $\begin{array}{l}\text { Secretary, stenographer, book- } \\
\text { keeper, librarian ................. }\end{array}$ & $3,372.23$ & $3,699.69$ & $3,341.93$ & \\
\hline Heads of departments.............. & $18,802.43$ & $13,499.67$ & $10,360.70$ & \\
\hline 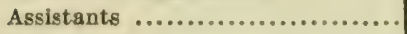 & $6,633.42$ & $7,433.19$ & $5,002.76$ & \\
\hline Labor in departments *........... & $7,157.18$ & $3,208.79$ & $2,949.92$ & \\
\hline Postage and stationery............ & 977.77 & 388.75 & 299.73 & \\
\hline Printing $\ldots \ldots \ldots \ldots \ldots \ldots \ldots$ & 770.14 & 942.10 & 864.47 & \\
\hline School furniture .............. & $2,549.88$ & 137.54 & 241.17 & \\
\hline Apparatus $\quad . . \ldots \ldots \ldots \ldots \ldots \ldots \ldots$ & $37,005.98$ & $1,598.08$ & $1,344.90$ & \\
\hline Subseriptions to periodicals....... & 49.70 & 118.43 & 94.25 & \\
\hline Library and reference books...... & $2,860.44$ & 139.22 & 271.68 & \\
\hline Guide...$\ldots \ldots \ldots \ldots \ldots$......... & …....... & 91.50 & ............ & \\
\hline Campus services .............. & ............ & 328.10 & & \\
\hline General labor ............. & 576.65 & (........... & .............. & \\
\hline Janitors $\ldots . . . . . . . . . . . . .$. & $1,382.92$ & $2,809.01$ & $2,364.61$ & \\
\hline Fuel $\ldots \ldots \ldots \ldots \ldots \ldots \ldots$ & $3,435.55$ & $6,049.42$ & $4,608.29$ & \\
\hline 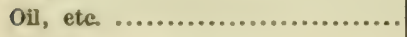 & 131.34 & 193.39 & 85.64 & \\
\hline \multicolumn{4}{|l|}{ Other: } & \\
\hline Horses and eattle............... & $5,893.82$ & 政 & 726.56 & \\
\hline Implements and tools....... & $2,602.99$ & 39.33 & (............. & \\
\hline Supplies $\ldots \ldots \ldots \ldots \ldots \ldots \ldots \ldots$ & $13,174.16$ & $9,610.28$ & $7,276.24$ & \\
\hline Labor in departments........... & $\ldots \ldots \ldots \ldots$ & $9,190,31$ & $8,202.40$ & \\
\hline Improvements .................. & $\cdots \cdots$ & $2,262.69$ & $1,371.85$ & \\
\hline \multirow[t]{2}{*}{ Repairs $\ldots \ldots \ldots \ldots \ldots \ldots \ldots \ldots$} & $\ldots \ldots \ldots \ldots \ldots$ & 961.04 & 488.92 & \\
\hline & $\$ 111^{\prime}, 236.48$ & $\$ 05,030.27$ & $\$ 52,500.02$ & \\
\hline Balance $. . . . . \ldots \ldots \ldots . . .$. & $\$ 20,397.12$ & $\$ 11,226.29$ & $\$ 16,100.80$ & \\
\hline
\end{tabular}

- Engineer, farm foreman, matron, only in last two years

† For perlod Jan. 1, 1912, to June 30, 1913. 
The fiscal year of the school corresponds with the calendar yeai. $U_{p}$ to the time of the change in administration the superintendent of the school made a quarterly financial statement to the county school board. The last report, made December 31, 1915, reported for the whole year. The accounting divisions are shown:

Statement for year ending Dec. 31, 1915.

Receipts:

Amount on hand Dec. $31,1914 . \ldots \ldots \ldots \ldots \ldots \ldots$

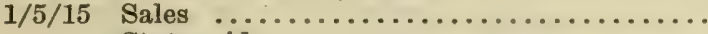

State aid $\ldots \ldots \ldots \ldots \ldots \ldots \ldots \ldots \ldots \ldots \ldots \ldots \ldots \ldots$

$\$ 122.55$

$9,999.90$

$7,000.00$

1st quar. allowance for sals. and supplies.

$4 / 7 / 15$ 2nd quar. allowance

$8,406.00$

$8,406.00$

Entire allowance for equipment.........

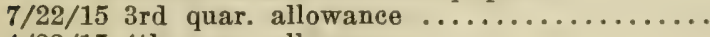

$4 / 22 / 15$ th quar. allowance

$10,570.00$

$8,406.00$

$8,406.00$

$\$ 61,316.45$

Disbursements

Administration:

Office $\ldots \ldots \ldots \ldots \ldots \ldots \ldots \ldots \ldots \$ \ldots, 231.65$

School in general............ $4,338.32$

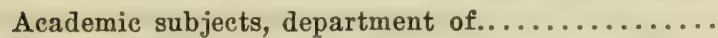

Dairy

Domestic economy,

$\ldots \ldots \ldots \ldots . . . . . .$.

Dormitory

Farm

Farm mechanies

Library

Horticulture

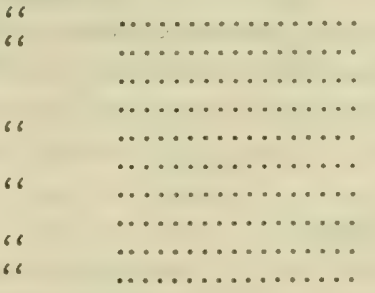

$\$ 10,569.97$

$2,427.52$

$7,557.33$

$3,433.53$

$4,673.20$

$6,135.27$

$3,424.58$

$1,291.08$

$4,390.45$

$8,608.41$

300.41

Music

Poultry

$3,185.25$

Balance 
DETAIL OF DISBURSEMENTS

\begin{tabular}{|c|c|c|c|c|}
\hline Department & Salaries & Supplies & Equipment & Total \\
\hline \multicolumn{5}{|l|}{ Administration: } \\
\hline office,$\ldots \ldots \ldots \ldots \ldots \ldots \ldots \ldots \ldots \ldots \ldots$ & $\$ 5,140.56$ & $\$ 1,062.31$ & $\$ 8.75$ & $\$ 6,231.60$ \\
\hline 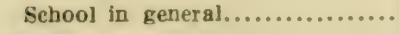 & $2,406.16$ & $1,428.54$ & 503.62 & $4,338.32$ \\
\hline Dairy ..................... & $4,093.22$ & $2,646.80$ & 817.22 & $7,5 \times 7.33$ \\
\hline Domestic Economy ............... & $2,518.14$ & 744.01 & 171.38 & $3,433.63$ \\
\hline Dormitory $\quad \cdots . . . \ldots \ldots \ldots \ldots$ & $1,777.05$ & $2,633.00$ & 263.09 & $4,673.20$ \\
\hline Farm $\ldots \ldots \ldots \ldots \ldots \ldots \ldots$ & $4,002.60$ & $1,800.61$ & 331.97 & $6,135.27$ \\
\hline Farm mechanies ............. & $2,819.96$ & 254.34 & 250.38 & $3,424.58$ \\
\hline Horticulture $\quad . . \ldots \ldots \ldots \ldots \ldots \ldots$ & $3,850.82$ & 242.83 & 196.80 & $4,390.45$ \\
\hline Library $\ldots . . . \ldots \ldots \ldots \ldots \ldots \ldots \ldots$ & 87.50 & 115.21 & 298.37 & $1,291.08$ \\
\hline light, heat and power............ & $3,703.26$ & $4,897.15$ & 8.00 & $8,608.41$ \\
\hline Music $\quad . . . . . . \ldots \ldots \ldots . . . .$. & 253.23 & 47.08 & ............. & 300.41 \\
\hline Poultry..................... & $2,004.89$ & 546.91 & 543.45 & $3,185.25$ \\
\hline \multirow[t]{2}{*}{ Academic subjects $\ldots \ldots \ldots \ldots \ldots$........ } & $2,309.92$ & 3.80 & 23.80 & $2,427.52$ \\
\hline & $\$ 36,037.50$ & $\$ 16,442.67$ & $\$ 3,516.83$ & $\$ 55,997.00$ \\
\hline
\end{tabular}

\section{History}

The cost for the first year of operation as shown by the reports to the state superintendent is much higher than for any other year. This is due to the fact that during the first year much apparatus, furniture and supplies were bought. It is also to be noted that more was paid for salaries, probably because of large enrollment, and that text books were purchased-a policy which has been discontinued. This year also includes receipts for a previous half year. Total cost has decreased since, but so, alsc, has total enrollment.

\section{Receipls-analysis}

Of the $\$ 68,696.82$ received for the year $1914-15, \$ 7,000$ cane from state aid. The previous year the state aid was $\$ 8,000$. Even had the attendance been kept up to the 1912-13 mark a change in the state law would have prevented the school from reciving mors than $\$ 7,000$ in $1914-15$. $\$ 55,423.43$ was the appropriation of the county. Of this $\$ 10,141.93$ was made up of moneys returned by the school to the county. This money came from sales and service performed by the school, such as sale of farm products and dormitory receipts. To the extent of these sales the cost of the school is offset. From tuition there was received $\$ 522$. Tuition is paid by the counties from which the pupils come and is charged to all from outside of Milwaukee County. The balance item was originally $\$ 11,226.29$. Of this the 
county board withdrew $\$ 5,474.90$, reappropriating $\$ 5,751.39$. This report is made out so as to end in the middle of the school's fiscal year and it is probable that the balances do not mean much at such a time. The total receipts for the year were $\$ 68,696.82$.

Expenditures-analysis

Total expenditures for the year 1914-15 were $\$ 52,590.02$. Of this capital expenditures, furniture, equipment, etc., cost $\$ 3,956.16$. Operation expenditures, $\$ 48,633,86$, were divided as follows: administration, $\$ 5,941.93$; instruction salaries, $\$ 15,372.46$; labor, $\$ 13$,606.93 ; supplies, fuel, etc., $\$ 12,364.15$; other, $\$ 1,348.39$. The balance remaining was $\$ 16,106.80$. According to the superintendent's report of December 31, 1915, the amount on hand at the end of the year was $\$ 122.55$.

Administration takes 12 per cent of the total operating cost.

Instruction salaries take 32 per cent of the total operating cost.

Labor takes 28 per cent of the total operating cost.

Supplies take 25 per cent of the total operating cost.

Other takes 3 per cent of the total operating cost.

These percentages and figures are surprising. Only 32 per cent of the total operating expense goes into teaching salaries. Only a slightly smaller percentage goes for labor. Supplies cost 25 per cent. That the salary proportion would be smaller in an agricultural school than in an ordinary secondary school is to be expected. The labor item would be expected to be high, also. But whether the difference should be so large is another matter. If farming were done on a large scale, as suggested in the preceding chapter, this proportion might be justifiable, for then more of the labor would actually be teaching. The reasons for the relatively small proportion for instructional salaries and the relatively large proportion for labor and supplies will be found in the cost of the upkeep of the too extensive plant, in the amount of hired labor, and in the completeness of the supplies purchased.

\section{Extension}

The cost of extension has already been approximately worked out in the chapter on extension (Chapter XI). No separate account is kept for this item. The estimated cost of $\$ 8,105.64$ is distributed among the various other items both in the report to the state and in the report of the superintendent to the board. As soon as possible extension costs should be separated from other costs.

\section{Per capita costs}

An accepted basis for calculating per capita cost has not as yet been anywhere worked out. Whenever such costs are given they must be ac- 
companied with an explanation of the method used, and what the cost found means. In this report per capita costs will be given on several different bases.

1. Gross per capita cost (all expenditures divided by average daily attendance).

2. Gross operating cost per capita (eliminating capital expenditures).

3. Gross operating per capita cost (including interest on investment).

4. Per capita cost as in 3 but eliminating extension and reducing average daily attendance by eliminating extension students.

5. Per capita cost to taxpayers (as in 4 but eliminating also amounts offset by sales).

Numbers 4 and 5 are the two methods which are recommended as accounting in the most satisfactory and complete way for all considerations. Number 4 is the total cost per student in regular attendance. This gives everything without regard to source of funds. Number 5 gives total cost to taxpayers and should be used in determining net cost to the county and state. The first three methods are given for purposes of illustration and explanation.

Before giving the results and methods for each of these bases, we shall insert the method worked out by the superintendent of the school and the result submitted to the county board of administration in a leiter dated January 28, 1916.

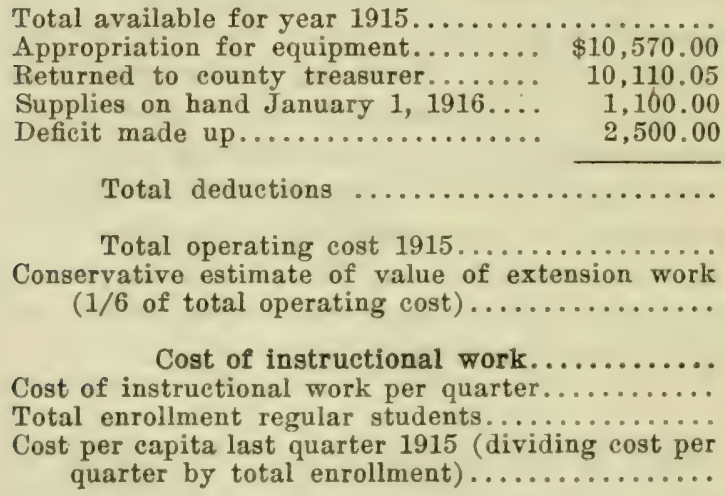

Does not include work with dependent home children.
$\$ 61,194.00$

$24,280.05$

$\$ 36,913.95$

$6,152.32$

$\$ 30,761.63$

$7,690.40$

198

$\$ 38.84$

40 enrolled.

This method is subject to several vital criticisms.

1. It is based on appropriations instead of on expenditures - that is, it gives what it is expected the cost will be rather than what it is.

2. The deduction for equipment assumes that equipment is not a cost. Either the total equipment or a proportional charge should be included. Actual expenditures for equipment in 1915 were $\$ 3,516.83$. 
3. No allowance is made for capital invested.

4. Supplies on hand are deducted, though the supplies items is an annual cost and this same amount may have been carried over from the previous year.

5. Returns to county treasurer are deducted. (This is an explanation, not a criticism. It means that the cost found is a net cosi to taxpayers, not a total cost of teaching the pupil.)

6. While cost of extension is subtracted the total enrollment given includes some whose work was considered in extension cost.

7. Cost per quarter is determined by dividing total cost by four, though students are at school for only three terms, which would correspond to three quarters. If the cost per quarter is multiplied by four to find the annual per capita cost this criticism does not hold.

8. Total enrollment is used as a divisor. Total enrollment is no indication of actual attendance. It puts the two weeks' student on the same basis as the year student. Average daily attendance is the nearest approach to actual attendance. Average daily attendance for 1914-15 including some extension students was 118.

\section{Method No. $1^{*}$}

This is the simplest and least scientific way possible. It is given here, merely because it is so often used by those who are not familiar with actual conditions. The total expenditures are divided by the average daily attendance.

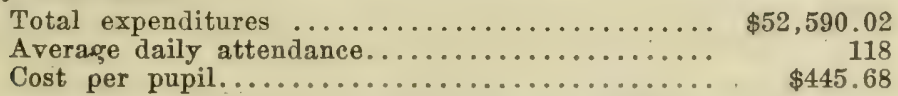

This figure cannot be taken as actual per capita cost. It does, of course, represent the amount of money which would not be spent if the school were not in existence.

Method No. 2

In this case we follow the method of No. 1 but eliminate expenditures for capital

$$
\begin{aligned}
& \text { Total expenditures .................. \$52,590.02 } \\
& \text { Capital expenditures ................ } 3,956.16 \\
& \text { Operating expenditures ............ \$48,633.86 } \\
& \text { Average daily attendance.................. } 118 \\
& \text { Cost per Jupil....................... \$412.15 }
\end{aligned}
$$

It is assumed here that capital expenditures are not charges that can be considered in cost per student. If there were new buildings their

- Allfficures used in this and following methods are for 1914-15. For reasons already given average daily attendance will be used for number of pupils. 
cost would here be excluded. So, also, with any charge on past investment. This method is open to the same objections as the preceding one.

Method No. 3

Total expenditures .................. \$52,590.02

Capital expenditures .................. 3,956.16

Operating expenditures ............ \$48,633.86

Add interest on investment $(346,000$ at $5 \%) \ldots \ldots \quad 17,300.00$

Average daily attendance..................................... 118

Cost per pupil....................... \$5.58.76

In figuring cost per pupil money invested for necssary land, buildings and equipment is part of actual cost. All of this cannot be charged to the students attending in the year when purchased or built, for in that case 1912-13 pupils would have been charged with an investment cost of over $\$ 300,000$. The equitable way is to distribute it according to benefit, and perhaps the best way of doing this is by means of an interest charge. If the term is not felt to be suitable, some other name (e. g., capital percentage, investment charge) may be used.

\section{Method No. 4}

Total expenditures .................. \$52,590.02

Capital expenditures ................. $\quad 3,956.16$

Total operation ............. \$48,633.86

Deduct extension '(1/6 of total operation)...... $8,105.64$

$4,400.00$

Net operation for regular pupils...........

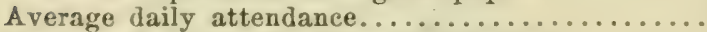
Cost per pupil (without capital charge).........

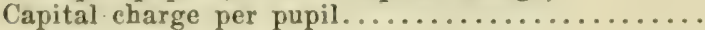

Total cost per pupil..................

$\$ 36,128.22$

108

$\$ 334.52$

160.19

$\$ 494.71$

This last figure, $\$ 494.71$, is the total cost per year for teaching one pupil. It is the figure which should be used when sources of funds are not considered. It is the answer to the question- "What is the total cost of educating one pupil one year?" The average daily attendance is reduced to 108 . The original figure of 118 includes some that are for cost purposes considered as extension. All short and special course sludents, including summer session and dependent home pupils, are called extension in dealing with extension cost. This is in ac- 
cordance with the policy of the school. Since extension cost is eliminated, extension pupils 'should also be eliminated. It is usual in figuring per capita costs for schools not to include a capital charge. If it is desired to make comparisons with other schools, it is safer to use the figure without a capital charge unless it is known that the other schools have made such a charge. Dormitory cost is deducted because the cost of rooming and boarding pupils is not part of teaching and it is offset by receipts from pupils for this purpose.

Method No. 5

Total expenditures

$\$ 52,590.02$

Deductions

Capital expenditures ......... \$3,956.16

Extension ................ 8,105.64

Sales, etc............... 10,141.93

Total

$22,203.73$

Net cost to county and state...........

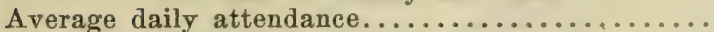

Cost per pupil without capital charge...........

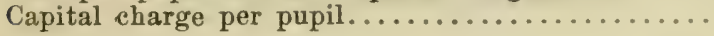

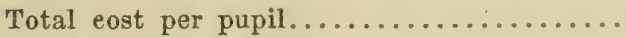

$\$ 30,386.29$

108

$\$ 281.35$

160.19

$\$ 441.54$

The difference between this and No. 4 is that in this method we find the total cost to the county and state of teaching one rergular full time pupil. $T_{0}$ find this there is deducted from total cost the amount offset by moneys returned by the school to the county treasury. These come from the sale of school products, from the dormitory, eic. The final figure is $\$ 441.54$ and is the correct figure to give when the total per capita cost to the county and state is asked for. The effort has here been made to give a fair and complete statement of per capita cost. Every item excluded or included has been explained. The method used by the superintendent of the school has been given with reasons why it is considered unsatisfactory. The method and result which it is felt are the most scientific and thoro have been indicated and are here recommended as the conclusion of the survey. Discussion of these costs will be taken up in the summary of finances at the end of this chapter.

Per capita costs for the three years of operation of the school

In finding per capita cost for the two preceding years the last method given is used. Capital investment was obtained by subtracting from present value the additions made each year. Extension was estimated at $\$ 6.000$ for $1912-13$ and $\$ 7,000$ for 1913-14. Average daily attendance was reduced to 140 the first year and to 130 the second 
year, so as to eliminate extension pupils. These figures are all as accurate as is possible with available data.

\begin{tabular}{|c|c|c|c|}
\hline & $1912-13$ & $1913-14$ & 1914-15 \\
\hline Cost I & $\$ 335.98$ & $\$ 332.42$ & $\begin{array}{r}\$ 281.35 \\
160.19\end{array}$ \\
\hline st per $\mathrm{p}$ & 103.93 & 131.54 & 160.19 \\
\hline Total per pupi & $\$ 43$ & $\$ 463.96$ & $\$ 441.54$ \\
\hline
\end{tabular}

Operating costs per pupil decreased slightly the second year and substantially last year. On the other hand, capital has been added at a rate which, when considered with the decrease in students, has forced up the total cost till last year's exceeds the first year's.

\section{Dormitory costs}

The dormitory is self-supporting if no account is taken of the investment. That is, it could be run at a profit as a private business if the building did not cost anything.

For the year 1915 receipts and expenditures were

Receipts

Cash (regular roomers and boarders)....... \$4,106.80

Cash (extra meals).................. 223.95

Transfers from other departments.......... 97.35

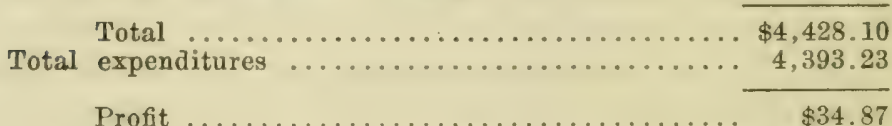

Profit

$\$ 34.87$

The building has accommodations for forty pupils. The highest number in residence at any one time this year was thirty-severi. The present number is twenty. While the dormitory for the year is self supporting, if investment is not considered, it would run at a substantial profit if it were kept full. Residence at the dormitory, including board, costs $\$ 4.75$ per week. The question which comes up, and which the superintendent is considering, is whether if the rate were reduced more pupils would not resicle in the dormitory. At present it is run on an unbusinesslike basis.

\section{Class costs}

By class costs is meant pupil cost per period for a single class. In this will be included only salary cost. The method used in finding this is as follows

Soils

Nine pupils in clas:

Teacher's salary is $\$ 113.33$ per month 
Teacher's salary: is $\$ 1.03$ per class hour

(26 hours of instruction per week-110 hours per month)

Cost per pupil per hour, $\$ .1144$

( $\$ 1.03$ divided by 9 , number in class)

Cost per hundred puipl hours $\$ 11.44$.

All of teaching is charged to instruction for all of the work that teachers do-preparing lessons, correcting papers, outside work, classroom work, etc. - is either directly or indirectly instructional work. The teacher's function is to teach, and all the work he does is chargeable to teaching. A possible exception is extension work. This, for direct aid to farmers, would take, according to the superintendent, one man's time two days a week. This is almost negligible for the whole faculty. Special classes are included in the number of teaching hours. Any other work is too small to make any material change in the results. This list does not include all subjects. Where two figures are given for the same they represent different sections.

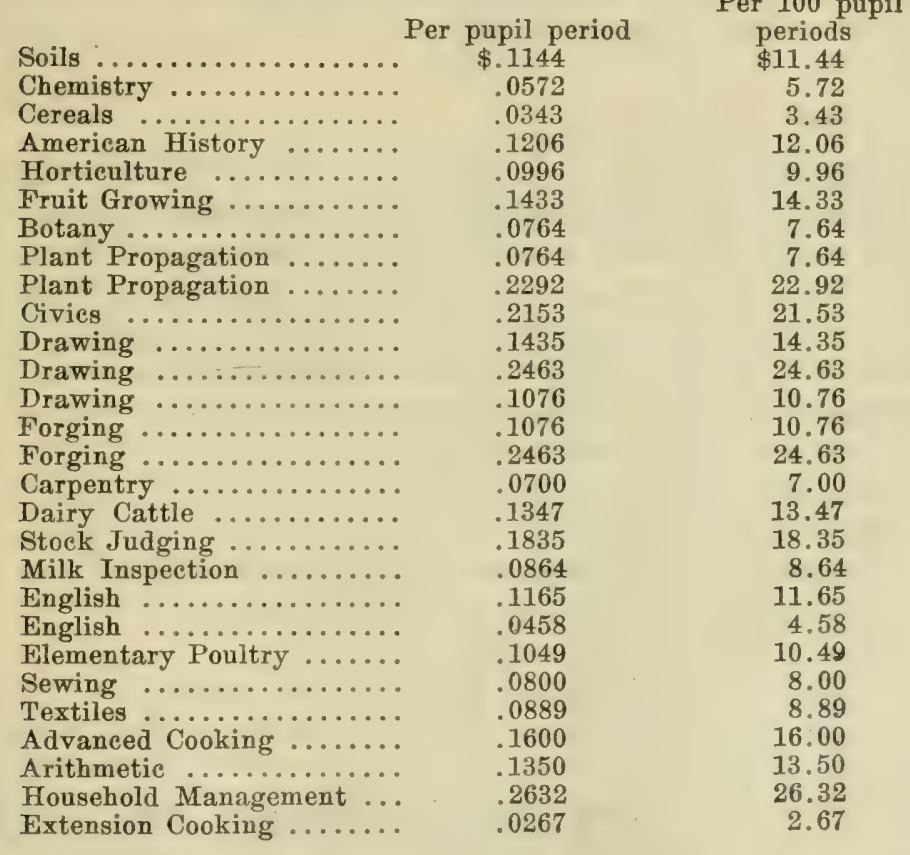

These costs represent only the instructional salary cost. Some of them are high and these are usually due to high salaried men with small classes. The cost of stock judging, for example, $\$ 18.35$ per hundred pupil periods, or $\$ 183.50$ per 1,000 pupil periods, is excess- 
ive. This class has eleven pupils and the teacher's salary is $\$ 1,820$ a year. Such cost figures kept up from year to year would help to show where costs were increasing and why.

\section{Accounting}

A new accounting system has recently been installed for the eight institutions under the board of administration. This system centralizes accounting in the general office. Its influence will be seen after it has had time to work thru a year or more.

\section{Purchasing}

Purchasing has also been centralized to some extent. The school still orders directly such supplies as are not common to all institutions. An effective checking system is in use in the school office. An experienced purchasing agent in charge of all purchasing would be able to effect savings in all county institutions.

\section{Budget Methods and Procedure}

Budget methods used are indefensible. The faculty submit to the superintendent their estimated needs. The superintendent revises as he sees fit, and submits them to the board of administration. After they approve, with such changes as they desire to make, the estimates are sent to the board of supervisors. The superintendent appears before this board to explain the budget. After it is passed by this board it becomes the financial authorization for the year.

The budget shows only requests.

No comparisons are given

No cost figures are given

No other supporting information of any kind is included

No investigation is made by any higher authority

No past expenditures are shown

Enrollment and attendance figures are not included

Work accomplished is not shown, nor are future plans with estimated costs

The budget is merely a collection of estimated needs. The first page contains the summary 
BUDGET, 1916-SUMMARY*

\begin{tabular}{|c|c|c|c|c|}
\hline Department & Salaries & Supplies & Equipment & Total \\
\hline Academic subjects $. . . . \ldots \ldots \ldots . . .$. & $\$ 2,400.00$ & ............. & $\$ 225,00$ & $\$ 2,625.00$ \\
\hline Administration $\ldots \ldots \ldots \ldots \ldots \ldots$ & $\begin{array}{l}4,870.00 \\
5,890.00\end{array}$ & $\$ 3,025.00$ & 200.00 & $\begin{array}{l}8,095.00 \\
9,115.00\end{array}$ \\
\hline Dairy $\ldots \ldots \ldots \ldots \ldots \ldots \ldots \ldots \ldots \ldots$ & $4,290.00$ & $1,795.00$ & $1,385.00$ & $7,470.00$ \\
\hline 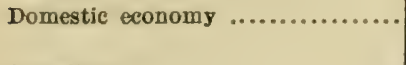 & $2,515.00$ & $\begin{array}{l}1,026.00 \\
1,026.50\end{array}$ & 265.00 & $\begin{array}{l}3,806.00 \\
3,806.50\end{array}$ \\
\hline Dormitory ......... & $\begin{array}{l}1,704.00 \\
2,004.00\end{array}$ & $\begin{array}{l}2,606.00 \\
2,750.00\end{array}$ & 100.00 & $\begin{array}{l}4,410.00 \\
4,854.00\end{array}$ \\
\hline 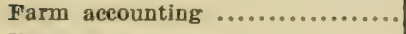 & $1,200.00$ & 25.00 & 85.00 & $1,310.00$ \\
\hline 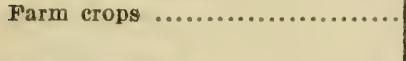 & $\begin{array}{l}3,920.00 \\
4,520.00\end{array}$ & 983.00 & 820.00 & $\begin{array}{l}5,723.00 \\
6,323.00\end{array}$ \\
\hline Farm mechanies ...... & $2,860,00$ & $56 \overline{0} .00$ & 100.00 & $3,525.00$ \\
\hline 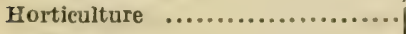 & $4,644,00$ & 450.00 & 685.00 & $5,779.00$ \\
\hline 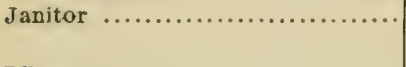 & $\begin{array}{l}1,620.00 \\
2,361.00\end{array}$ & 270.00 & 500.00 & $\begin{array}{l}1,890.00 \\
3,131.00\end{array}$ \\
\hline Library .......................... & 925.00 & 140.00 & 120.00 & $1,185.00$ \\
\hline Light, beat and power............ & $\begin{array}{l}3,360.00 \\
3,560.00\end{array}$ & $6,378.48$ & ........ & $\begin{array}{l}9,608.48 \\
9,898.48\end{array}$ \\
\hline Music .. & 300.00 & $\$ 5.00$ & & $\mathbf{3 3 5 . 0 0}$ \\
\hline 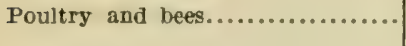 & $2,350,00$ & 695.00 & $1,270.00$ & $4,315,00$ \\
\hline Totals..... & $\begin{array}{l}\$ 36,819.00 \\
\$ 39,819.00\end{array}$ & $\begin{array}{l}\$ 17,918.48 \\
\$ 18,097.98\end{array}$ & $\begin{array}{l}\$ 5,255.00 \\
\$ 5,755.00\end{array}$ & $\begin{array}{l}\$ 59,831.48 \\
\$ 63,671.9 \$\end{array}$ \\
\hline
\end{tabular}

SUGGESTED GENERAL IMPROVEMENTS

Fixing up road,-lighting and curb.

$\$ 1,500.00$

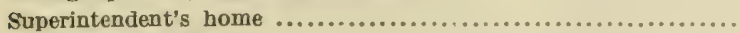

New beating plant.

Auto truck

Farm tractor

$2,500.00$

$25,200.00$

$2,000.00$

$5,000.00$

$1,000.00$

$\$ 3 \%, 000.00$

$\$ 1,500.00$

The italic figures are the requests which were denied. The figures above are the actual allowances. It is noticeable that of $\$ 37,000$ for suggested general improvements only $\$ 1,500$ was allowed. On the information given these reductions must have been arbitrarily made. The detail was given in the following form

*This table as taken from the school budget does not.check exactly. 
Department of Academic Subjects

Salaries

Head

Hixtra help

Equipment

(\$400 extra help for new instruetor. If granted $1 / 3$ of salary chargeable to present year)

Department of Administration and Sehool in General Salaries

ete.

Running expense

-...

etc.

Equipment

etc.

This shows the entire amount of detail and information given. The following cuts and eliminations were made

Department of Administration

Bookkeeper (bookkeeping transferred to general oflice ) .................... \$1,020.00

Department of Domestic Economy

Sewing laboratory supplies.............. $\quad .50$

Dormitory

1 maid ........................ 300.00

Groceries. butcher, milk.............. 144.00

Farm erops Janitor

2 hired men $(6$ mos.)............... 600.00

1 assistant janitor $\ldots \ldots \ldots \ldots \ldots \ldots . \$ \$ 696.00$

1 janitor .................. 90.00

3 assistant janitors (students 9 mos.
each) .................... 540.00

Extra belp for special occasions..... $\quad 75.00$

$\$ 1,401.00$

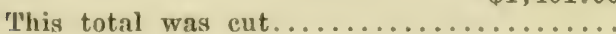

Vacuum cleaner for administration building.........

Light, heat and power

Music

Engineer from 1400 to $1200 \ldots \ldots \ldots \ldots \ldots \ldots .200 .00$

Salaries ....................... \$00.00

Supplies .................. $\$ 5.00$

Total salary euts below requests (not reductions on

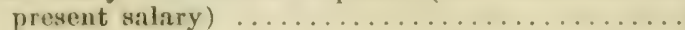

Total supplies budget cuts.................. 179.50

Total equipment budget euts............. 500.00

Suggested improvementg cut............. $35,500.00$ 
Even with these cuts there was an increase over 1915 expenditures of over $\$ 5,000.00$ and this in the face of a decreasing attendance. The expenditures for the year 1915, as shown in the report of December 31,1915 , are given in the early part of this chapter.

Can the county board of administration, and the county board of supervisors know how much money the school needs without a comparison of expenditures and requests, without detailed cost figures of the kind shown in this report, and without further detailed supporing data?

The budget should show for every item of request the expenditures for the previous year or two years, increase or decrease requested with reason for change, and a program of work expected to be accomplished in the year for which the budget is made with estimates of conts for this work.

Information needed by budget body

Requests-detail and summary

Past expenditures-detail and summary

Increases and decreases-detail and summary

Reasons for changes

$\mathrm{Per}$ sapita costs

Class costs

Farm costs-expenses and sales

Departmental costs of all kinds

Work program for year

\section{Summary of Finance}

The history of the school shows that ever since its beginning it has been working on an inflated basis of cost. It has the habit of extravagance so firmly fixed that it feels that any extensive cut in its support would be impossible. Per capita cost is excessive. $\$ 335.00$ per pupil per year, which counts no charge for investment, is indefensible. That such cost should have continued year after year is due to inflation in the beginning which has not been overcome, small and decreasing number of pupils, too extensive equipment, inadequate budget methods, and the attempt, perhaps unconscious, to teach boys and girls of high school age and preparation in a plant suitable for a small college. Even the best of results would not justify the cost, and the short-comings noted in this report do not show that the work is of the best. Cost ought to be very materially reduced and the work in many directions materially bettered before the taxpayers of Milwaukee County can feel that they are securing returns commensurate with their initial and annual investment. 





\section{LIBRARY OF CONGRESS}
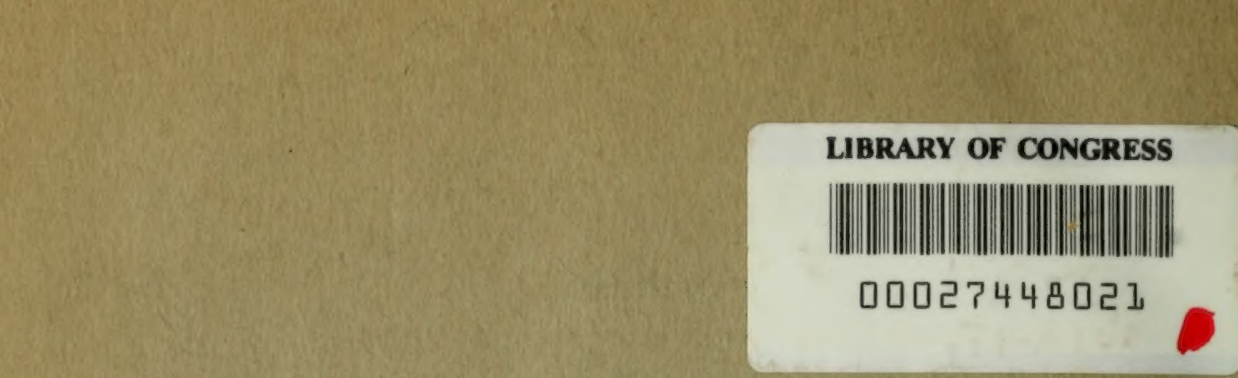

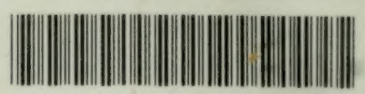 \\ 00027448021}

